IZA DP No. 8462

Top Team Diversity and Business Performance:

Latent Class Analysis for Firms and Cities

Max Nathan

September 2014 


\title{
Top Team Diversity and Business Performance: Latent Class Analysis for Firms and Cities
}

\author{
Max Nathan \\ London School of Economics, \\ NIESR and IZA \\ Discussion Paper No. 8462 \\ September 2014
}

IZA

P.O. Box 7240

53072 Bonn

Germany

Phone: +49-228-3894-0

Fax: +49-228-3894-180

E-mail: iza@iza.org

Any opinions expressed here are those of the author(s) and not those of IZA. Research published in this series may include views on policy, but the institute itself takes no institutional policy positions. The IZA research network is committed to the IZA Guiding Principles of Research Integrity.

The Institute for the Study of Labor (IZA) in Bonn is a local and virtual international research center and a place of communication between science, politics and business. IZA is an independent nonprofit organization supported by Deutsche Post Foundation. The center is associated with the University of Bonn and offers a stimulating research environment through its international network, workshops and conferences, data service, project support, research visits and doctoral program. IZA engages in (i) original and internationally competitive research in all fields of labor economics, (ii) development of policy concepts, and (iii) dissemination of research results and concepts to the interested public.

IZA Discussion Papers often represent preliminary work and are circulated to encourage discussion. Citation of such a paper should account for its provisional character. A revised version may be available directly from the author. 


\section{ABSTRACT}

\section{Top Team Diversity and Business Performance: Latent Class Analysis for Firms and Cities}

A growing number of studies find linkages between workforce diversity and business performance, but key aspects of this relationship remain unclear. First, within the firm, the role of 'top team' demography on firm outcomes is surprisingly little understood. Second, urban location may amplify firm-level processes, but almost no studies test these firm-area interactions. I deploy English cross-sectional data to explore these issues, using latent class analysis to tackle firm-level heterogeneity. I find evidence of positive links in some firm classes, both linear and non-linear, and suggestive evidence that ethnic top team diversity is amplified in the London city-region.

JEL Classification: J15, L21, R23

Keywords: firm-level analysis, business performance, diversity, ethnicity, gender, cities

Corresponding author:

Max Nathan

London School of Economics

Houghton St

London, WC2A 2AE

United Kingdom

E-mail: m.a.nathan@Ise.ac.uk

\footnotetext{
* The research is supported by LLAKES, and makes use of microdata from the RDA National Business Survey. Many thanks to Patrick Bowes, Adam Swash, Richard Woolhouse and Jonathan Wood for use of the data, to Sachin Dodhia for technical support, and to Dave Maré for discussions on methodology and interpretation. Thanks also to Jessie Bakens, Thomas De Graaff, Geoff Mason, Ceren Ozgen, Jacques Poot and Cinzia Rienzo, and to participants at the Urban Economics Association Summer conference 2013, NORFACE conference 2013, and workshops at LLAKES and the Tinbergen Institute for helpful comments on previous drafts. The opinions in this paper are those of the author, not those of the funders or data providers. Any remaining errors and omissions are my own.
} 


\section{Introduction}

This paper asks: what are the links between the demographic composition of 'top teams' in firms, and the performance of those firms? In particular, what roles might ethnic or gender diversity play in shaping firm revenues?

These questions are highly relevant to public and policy debate. Gender equality is a longstanding policy agenda. And as many Western countries become more ethnically diverse, commentators debate whether more cosmopolitan societies are economically or socially desirable (Florida, 2002; Gilroy, 2004), or whether such diversity has costs (Collier, 2013; Goodhart, 2013). Understanding where changes may take place is of critical importance. To date, most empirical analysis has focused at area level (for reviews see Nathan (2012), Kemeny (2014) and Lewis and Peri (Forthcoming)). However, many economic impacts occur within firms (Kerr, 2013). In theory, diversity in firms has ambiguous effects on company performance. More diverse workforces may be more creative and innovative, improve market access or allow for greater task specialisation; conversely, trust may be lower, making organisations less efficient. A small but growing number of firm-level studies have tested links between workforce diversity and business outcomes, most finding some positive effects (Nathan, 2012; Azmat and Petrongolo, Forthcoming).

Key aspects of these diversity-performance links remain unclear. First, are linkages linear or non-linear? If so, there may be 'optimal' levels of diversity (Ashraf and Galor, 2013). Second, do links operate differently within the firm? The demographics of a firm's owners, partners and 
directors - the ‘top management team’ - seem highly salient (Hambrick and Mason, 1984). Third, are there interactions between firm demography and area characteristics? In particular, ethnic diversity 'effects' in firms may be amplified in cities through agglomeration economies, urban diversity or both.

I use a cross-sectional dataset of over 2,000 English firms to explore these issues. My data allows me to specify ‘top management team' (TMT) ethnic and gender diversity, as well as a range of firm characteristics and outcomes. Building on work by Ozgen and De Graaff (2013), I get closer to causality by using finite mixture modelling to tackle unobserved firm-level heterogeneity (Heckman and Singer, 1984): this approach also allows for rich descriptive analysis of firm classes within the sample. Overall, I find some evidence of positive diversity-performance associations. However, ethnic and gender TMT diversity have varying relationships to firm turnover within firm classes, and relative to each other. The largest and most established companies show a linear link from ethnic diversity to revenue; other groups, predominantly businesses that are smaller and less formalised in working structures, seem to have non-linear relationships (U-shape for ethnic diversity, N-shape for gender). Strikingly, I find some signs of capital city amplification ‘effects’ for the smallest, youngest and most financial servicesorientated firms. By contrast, second tier metro locations exhibit decreasing effects.

The paper is one of very few to combine within-firm and urban scale analysis in this way. Nathan and Lee (2013) look at top teams for London firms. Trax et al (2012) and Lee (2014) explore firm-city interactions, but for the whole workforce (and in Lee, only for a cross-section of SMEs). Ozgen and De Graaff (2013) use a latent class approach for Dutch data, but are unable 
to distinguish senior staff. The paper thus contributes to the growing 'economics of diversity' literature (Nathan, 2012), to the established literature on gender and business performance (Azmat and Petrongolo, Forthcoming), to work on high-skill migration (Kerr, 2013) and on management teams (Certo et al., 2006).

The paper is organised as follows. Section 2 sets out a simple framework and reviews relevant empirics. Section 3 introduces the data. Sections 4 and 5, respectively, cover identification and estimation issues. Section 6 gives descriptive analysis, while Section 7 presents the main results and robustness checks. Section 8 extends the analysis to urban areas. Section 9 concludes.

\section{Framework}

Intuitively, 'diversity’ refers to the mix of groups in a society, or as in this case, the mix of individuals in a group. Following Ottaviano et al (2007), I define ‘diversity' in terms of number (of identity groups) and evenness (of groups’ distribution).

In theory, the link from top management team demographics to business performance metrics such as turnover is ambiguous. One view is that diverse teams may benefit from a wider range of ideas, perspectives and experiences than homogenous teams, which may raise organisational creativity (Page, 2007). These effects may be particularly important in knowledge-intensive industries, or in problem-solving situations in any firm (Mannix and Neale, 2005). Ethnic diversity may also raise performance via network externalities - for instance, diasporic links to 
‘home’ countries that improve market access (Foley and Kerr, 2013). Co-ethnic networks may also lower transactions costs and aid knowledge diffusion, which has become increasingly important under globalisation (Docquier and Rapoport, 2012). Ethnic diversity - for example from immigration - may also facilitate greater task specialisation (Peri, 2012). Conversely, trust and bonding social capital may be lower in diverse teams than for homogenous groups, so that decision-making is harder and organisations become less productive (Alesina and Ferrara, 2005). Some diasporic links may be more valuable than others. Female or minority-dominated top teams may also experience greater discrimination from suppliers and investors than homogenous firms.

Firm-level empirical research to date has tended to focus on overall workforce diversity. Ethnicity analysis is still relatively rare. Studies by Ozgen et al (2013) and Parrotta et al (2014a; 2014b) find positive links from ethnic diversity to firm innovation and productivity. Conversely, Maré et al (2013) and Maré and Fabling (2011) find no such links. Kerr et al (2013) link skilled migration to higher employment in US firms; Foley and Kerr (2013) suggest that skilled migrants help US multinationals access migrants' 'home' countries. Gender analysis is more common (for a review, see Azmat and Petrongolo (Forthcoming)) and typically suggests that gender diversity has positive effects on business performance. In a recent study of Dutch retail, for instance, Delfgaauw et al (2013) find that gender-balanced stores perform best in a sales tournament. Lab studies by Apesteguia et al (2012) and Hoogendoorn and van Praag (2013) also suggest that gender-diverse teams perform better than homogenous teams in sales games.

Three areas of the field are less well explored. First, the shape of a given diversity-performance relationship may not be linear (Ashraf and Galor, 2013). As Ashraf and Galor point out, this 
may also vary across country or sector contexts. In Danish firms, for instance, Ostergaard et al (2011) find no evidence for ethnicity or gender non-linearity; by contrast Lee (2014) finds Nshaped links from ethnic diversity to innovation in UK SMEs.

Second, diversity-performance channels may operate differently within the firm. Senior management demographics may have particularly important impacts, given that 'top teams' take strategic decisions and set the overall direction of the business (Hambrick and Mason, 1984). TMT empirical literature highlights the importance of top team demographics (Certo et al., 2006; Adams et al., 2010), but surprisingly few studies look at ethnicity and gender dimensions of TMTs. One exception is Ahern and Dittmer (2012) who suggest that the introduction of gender quotas for Norwegian company boards led to less-experienced top teams in the short term, lowering profits.

Third, there may be important interactions between firm demography and area characteristics. In particular, the productivity-enhancing effects of cities or urban locations may amplify ethnic diversity-performance channels in firms. Urban demographics may also play a role, if diverse urban milieux present larger local markets to sell into. Conversely, urban segregation may limit the potential for diverse firms to generate sales outside specific communities. A number of arealevel studies find positive connections from diversity to aggregate economic outcomes (see Nathan (2012) for a review of this literature). However, very few studies explicitly examine firm-urban linkages. Trax et al (2012) find strong evidence of spillover effects from area-level cultural diversity to German firm performance, and from workforce diversity to regional outcomes. In the UK, Nathan and Lee (2013) find that firms in London benefit from diverse 
home markets. However, Lee (2014) finds little evidence of links between urban demographics and SME innovation.

\section{Data and variables}

Data is drawn from the UK Regional Development Agencies’ National Business Survey (hence NBS), which was conducted every year from 2003 through to 2009 across the nine English regions and Northern Ireland (the Agencies were formally abolished in 2011). ${ }^{1}$ The NBS included questions about owner/partner ethnicity and gender in 2008 and 2009. I use the 2008 cross-section, which provides the most detailed turnover information. The raw data for England comprises 2,381 observations, weighted by employee numbers and region (Ipsos MORI, 2009).

The NBS has strengths and weaknesses. The UK has surprisingly few rich sources of firm-level data, and the NBS is a single source that asks detailed questions about business performance and constraints, as well as top team and firm characteristics. Importantly, the data allows me to separately identify diversity and sameness information along multiple dimensions, alongside multiple measures of business performance. The NBS also includes industry codes at up to fourdigit level and detailed spatial identifiers for NUTS1-3 areas, enabling me to fit detailed fixed effects alongside firm-level controls. As such it is substantially more informative than other business-level datasets such as the ARD, and fuller in its coverage than other UK surveys. Conversely, some questions vary from year to year, and there is no panel structure to the data.

\footnotetext{
${ }^{1}$ The full list of regions is the North East, North West, Yorkshire and Humber, West Midlands, East Midlands, East of England, South East, London and the South West.
} 
The NBS also does not ask directly about individual or workforce human capital. To deal with this, and to generate relevant area-level controls, I use detailed small-area level workforce and demographic information from the Annual Population Survey (APS), which contains a boosted local sample that allows for reliable sub-regional estimates. ${ }^{2}$

More broadly, innovation survey data has pros and cons. It avoids some of the constraints in patents analysis, such as manufacturing skew, vulnerability to policy / industry shocks and lack of explicit quality measure (OECD, 2009). On the other hand, surveys risk a response bias towards innovating firms and may capture trivial developments (Smith, 2005). The NBS deals with the first issue through careful sampling and with the second through focusing explicitly on 'new innovations'; this may be easier to identify for new products than for new processes. ${ }^{3}$

\subsection{Key variables}

Business turnover information is simply organised into seven bands, ranging from 'up to $£ 49,000$ / year' to ' $£ 5 m+$ / year'. ${ }^{4}$ I use the midpoints of these bands (£25,000, $£ 75,000, £ 125,000$ and so on) to fuzzily illustrate effect sizes from changes in the independent variable, TMT diversity. Building on Ottaviano et al (2007), I construct a linear measure of TMT diversity based on the

\footnotetext{
${ }^{2}$ The Annual Population Survey (APS) combines results from the English Labour Force Survey (LFS) and the English, Welsh and Scottish LFS boosts, and asks 155,000 households and 360,000 people per dataset about their own circumstances and experiences regarding a range of subjects including housing, employment and education.

${ }^{3}$ The precise wording is: " Has your business introduced a new product or process innovation in the last 12 months? And do you expect to introduce a new product or process innovation in the next 12 months?"

${ }^{4}$ The full coding for turnover is 1 (up to $\left.£ 49 k\right), 2$ (£50-99k), 3 (£100-499k), 4 (£500-999k), 5 (£1-1.99m), 6 (£2$4.99 \mathrm{~m})$ and $7(£ 5 \mathrm{~m}+)$.
} 
underlying shares of minority ethnic and female team members. The variable is 'folded' to take a maximum value of 0.5 , corresponding to maximum evenness in the underlying groups in firm $i$ :

$$
\operatorname{DIV}_{i}=0.5-\left|S H A R E_{i}-0.5\right|
$$

DIV has a minimum value of 0 (corresponding to SHARE of 0 or 1 , homogeneity); when the underlying minority/female share is 0.25 or 0.75 , DIV takes the value 0.25 . It is of course possible that (say) 25\% and 75\% female TMTs are qualitatively different. Also, these diversity measures say nothing about types of TMT homogeneity. In a second stage I unpack these issues by fitting dummies for all-male/female and all-minority/majority TMTs.

Testing for non-linearity is not straightforward. In the NBS data the majority of firms have nondiverse TMTs - for example, the average share of minority TMT members is under 4\% (see Table 1). That implies a conventional polynomial may be hard to fit. Alongside the linear measure, therefore, I fit a dummy taking the value 1 if the TMT has any heterogeneity. This allows me to separate a) the 'effect' of at least some TMT diversity versus homogeneity and b) the slope of the TMT diversity coefficient for diverse firms, providing a rough sense of whether a nonlinear link is present. For gender diversity I am also run regressions with a quadratic term.

\subsection{Descriptives}

Table 1 provides summary statistics. Average turnover is between $£ 100-499 \mathrm{k}$ (corresponding to the ' 3 ' band in the data). Firm TMTs are notably non-diverse in ethnicity terms, with the average 
top team having 3.5\% minority ethnic members and 2.8\% of firms with all-minority TMTs. Firms are more diverse in gender terms, with an average of $25 \%$ female representation on the TMT and just over $10 \%$ of firms with all-female top teams. Table A1 in Appendix 1 provides a correlation matrix for these main variables. This shows negative (simple, pairwise) correlations between TMT minority/female shares and turnover, but positive diversity-turnover links, which are significant at 5\% for both ethnicity and gender.

\section{Table 1 about here}

The average firm is 6-9 years old (banded ' 3 ' in the data) and has around 20 staff outside the TMT (the largest firm having over 12,000 employees). Almost 75\% of firms are independents; fairly few are exporters or use foreign inputs; around a third have a formal business growth plan or provided training to staff in the past year. Around a quarter report some product or process innovation in the last year; nearly $2 / 3$ expect to invest in R\&D in the coming year; but only a minority have formalised ‘innovation links’ to universities or through specialist networks.

\section{Identification}

Identifying causal effects of team characteristics on firm-level outcomes throws up a number of challenges that will bias OLS coefficients. First, we need to control for wider contextual or areaspecific factors that may drive firm outcomes - for example, a technology shock might simultaneously raise firm performance and change TMT demographics (say, if firms seek to 
recruit experts in that technology). We also need to be able to cleanly pick out area-level characteristics of interest. Second, we need to separate senior team characteristics from those of individual members, and the wider firm, characteristics not always observable (Adams et al., 2010). Both of these issues lead to spurious correlations if not dealt with.

Third, we need to deal with simultaneity, at both area and firm levels. Successful firms may select into the largest markets, which ceteris paribus will tend to have larger and more diverse populations. Not controlling for this leads up to (likely) upward bias in diversity coefficients (Card, 2010). Similarly, if businesses observe a positive (negative) effect of top team composition on business performance, they may adjust team composition to maximise (minimise) any positive (negative) consequences for the firm (Ozgen et al., 2013; Parrotta et al., 2014b).

\subsection{Identification strategy}

The cross-sectional nature of my data means that within-firm selection issues cannot be eliminated. I partially control for area-level selection using historic area-level demographic information, but am unable to instrument for these or exploit an exogenous shifter. The analysis therefore provides associations, rather than causal effects: the identification strategy is then to render these linkages as cleanly as possible.

I deal with observables using a combination of firm-level controls, plus industry and area fixed effects that handle sector context and time-invariant area characteristics. I test alternative urban 
hierarchy measures to identify capital / core city interactions. I also select an analysis year, 2008, in which turnover-boosting external shocks are unlikely to occur or have occurred in years immediately preceding.

To tackle unobservables at firm level, I build on the approach of Ozgen and De Graaff (2013) and use Finite Mixture Modelling (FMM). FMM is a type of latent class estimation that is essentially a variant on unsupervised machine learning techniques (Hastie et al., 2009). Learning routines are computationally intensive and have only recently become popular, particularly in Big Data settings (Varian, 2014). FMM has been used in a range of science and social science fields, as well as a few cases in economics and the social sciences (Heckman and Singer, 1984; Baum-Snow and Pavan, 2012; Brown et al., 2014).

FMM provides a natural representation of unobserved heterogeneity by probabilistically splitting the sample into a number of homogenous latent classes or 'components' (Deb, 2008). The 'mixture’ of classes is estimated semi-parametrically as multinomial logit probabilities in maximum likelihood: the same statistical model applies, but each class has different parameters of the distribution, allowing explanatory variables to have differing effects across components (Brown et al., 2014). The distribution of the dependent variable is typically used to specify likely densities. In this case business turnover is roughly normally distributed (see Figure 1), so the model is estimated as a 'mixture of normals'.

Figure 1 about here 
The FMM estimator solves iteratively for models based on 2, .. C latent classes, with the optimal model determined through model selection and actual convergence. Increasing $C$ mechanically improves model fit statistics, but models with many components are less parsimonious and more complicated to interpret (Heckman and Singer, 1984). I am able to achieve convergence for up to five components: Appendix 2 provides diagnostic tests for these different models. Given the relatively small sample, an additional concern is to minimise the number of components with under 100 observations, since modelling will be based on sparse information, inference may not be reliable and small classes may also be driven by outliers rather than group-homogenous characteristics (Deb, 2008). Overall, a three-component model best fits the distribution of turnover in Figure 1, with the biggest gains in model fit from smallercomponent models, while still allowing for robust and parsimonious interpretation.

FMM estimation introduces additional complexity to the analysis, and as with all structural models, identification is not always straightforward compared to OLS (Angrist and Pischke, 2009). However, as Ozgen and De Graaff (2013) point out, in this case the FMM approach has a number of useful features: it allows endogenous assignment of observations to specific classes, and allows comparison of these sub-sample outcomes to average associations across the whole. It thus allows us to test whether diversity-turnover linkages differ across different groups of firms, and to explore the characteristics of those groups in some detail. ${ }^{5}$

\footnotetext{
${ }^{5}$ Alternative candidate identification strategies would include a control function or a Heckman selection model. I have experimented with both of these approaches. Control function estimates are unstable and highly sensitive to choice of controls. Heckman estimation requires a plausibly exogenous selection variable, which is hard to identify in this instance.
} 


\section{Model and estimation}

I fit a production function model for firm $i$ in sector $j$ and area $a$ :

$$
\mathrm{Y}_{i j a}=\mathrm{f}\left(\text { EDIVb }_{\mathrm{ija}}, \text { FDIV }_{\mathrm{ija}}, \text { CTRLSd }_{i j a}, \text { CTRLS }_{a}, \mathrm{~J}_{j}, \mathrm{~A}_{a}, \mathrm{u}_{i j a}\right)
$$

Where $\mathrm{Y}$ is banded turnover, EDIV is top management team ethnic diversity, 'folded' to a maximum of 0.5 as described in section 3.1, and FDIV is defined identically for TMT gender diversity. I fit both linear TMT diversity measures and the 'diversity dummy' in the main analysis. I interpret coefficients $b$ and $c$ as average marginal 'effects' (associations).

The controls vectors are populated from the existing business performance literature. Firm-level controls (CTRLSdija) include firm age, number of non-TMT employees, number of owners / partners, firm legal status, workforce development activity, growth plans and operating capacity. Larger and more established businesses are likely to have higher turnover; age and size may also affect TMT demographics (Haltiwanger et al., 2013). Company type is likely to influence performance, since subsidiaries benefit from both financial and informational resources from parent firms (Javorcik, 2004); such corporate structures may also influence TMT choices. I thus fit dummies for UK subsidiaries, foreign subsidiaries, ultimate holding companies, independents and LLPs, with ‘unknown’ the reference category.

Firms' human capital, whether in the workforce or in management may turn out to explain apparent TMT 'effects’ (Parrotta et al., 2014a). To get an approximate fix on firms' human 
capital I fit dummies for whether firms have attempted to improve their skills base through training (no training being the reference category); in robustness checks I complement this with area-level skilled workforce measures. Similarly, to approximate managerial capacity I fit dummies taking the value 1 if the firm has a codified growth plan and if it is operating at capacity.

Crucially, the area-level vector CTRLSea provides partial controls for area-level conditions that may affect both firm performance and TMT demographics. Urban location helps firms to become more productive via agglomeration economies, raising turnover (Rosenthal and Strange, 2004); urban areas also tend to have more diverse populations, which may influence top team characteristics. To control for this I fit the natural log of NUTS2 population density, lagged to 2001. TMT characteristics may collapse to other characteristics of the wider area population too; besides population density, I also fit controls for a given area’s minority ethnic population share in 2001. Finally, J and A represent one-digit industry and NUTS2 fixed effects. Standard errors are clustered on SIC1.

I estimate FMM results with maximum likelihood. For comparison I run OLS regressions on the whole sample, for direct comparison of average marginal 'effects' and those for latent classes. ${ }^{6}$

\footnotetext{
${ }^{6}$ A potential alternative estimator to OLS would be an ordered logit, given that turnover is strictly banded rather than continuous. However, each band is quantified so this approach is less appealing in practice, and the required proportional odds assumption may not hold.
} 


\section{Descriptive analysis}

Table 2 provides diagnostic information that summarises the 'performance' of the threecomponent FMM model, drawing on the tests described in Appendix 2.

Table 2 about here

The top panel provides the classification of subjects based on posterior probabilities, which specify the probability that firm $i$ belongs to class $C$ given that we observe firm turnover: these comprise $28.8 \%, 58.2 \%$ and $19.9 \%$ of the sample. The middle panel shows average posterior probabilities for each class: that is, the underlying probability of a firm assigned to C1 truly being in C1. This suggests assignment is fairly clean, ranging from 0.729 to 0.887 . The bottom panel presents a range of model fit statistics. Entropy is of particular interest, and ranges from 0 (every firm has an equal posterior probability of membership in all classes) to 1 (each firm has posterior probability 1 in a given class). Here, the entropy score of 0.574 suggests assignment is significantly better than random. Log-likelihood for FMM models is substantially better than in OLS regressions (see Table 5).

\subsection{Characteristics of the latent classes}

Table 3 summarises the mean characteristics of the pooled sample and each of the latent classes. As the latter are probabilistic, rather than observed, I also provide a class-weighted average 
measure. This gives the implied sample average, and functions as a further crosscheck on the modelling: the closeness of the modelled and observed sample means is reassuring.

\section{Table 3 about here}

The top panel of Table 3 compares components according to the variables of interest and controls. Overall, C1 firms emerge as the largest, most successful in turnover terms and most formalised in terms of structures and workflows. Component 1 firms have the highest turnover by some way (over £500k), with component 2 firms in the middle (£100-499k) and component 3 firms the lowest, at under £100k on average. However, component 3 firms have the highest minority ethnic and female TMT shares, and the greatest incidence of all-minority / all-female TMTs. Component 1 firms are much larger than those in other components, with over 62 staff (compared to 7 and 4 for C2 and C3 respectively). By contrast, there seem to be few age differences between classes. Component 1 firms are the least likely to be independent, although shares are high across all classes; component 1 firms are also the most likely to have a formal growth plan; to have trained staff; and to have formal linkages for R\&D and information gathering. On each of these, C1 is followed by C2 with C3 firms being the least likely to have those characteristics.

The second panel gives industry breakdowns at SIC1 level. Component 1 firms are orientated towards manufacturing, distribution and public /personal services compared to the weighted average, component 2 towards hotels / catering and financial intermediation. Component 3 is 
similar to component 2 but with more of a skew: this class also has the highest share of primary industries.

The bottom panel gives the basic spatial distribution of the classes, using a Eurostat four-fold typology of city-regions. More than 2/3 of firms are in some kind of urban area, both overall and within classes. This broad urban orientation is highest for $\mathrm{C} 1$ firms, as is the 'big city' orientation (capital cities and second tier metros). On this basis, C3 firms seem the least urbanised. However, city-regions typically encompass multiple NUTS2 areas. Table A1.2 provides finergrained analysis at NUTS2 level: this shows that C3 firms have the highest representation in Inner and Outer London, with C2 firms in the middle and C1 firms least London-based.

\section{Regression analysis}

This section sets out the main results of the regression analysis. I begin with simple OLS results, comparing these to FMM regressions. I then run a number of robustness checks.

Table 4 sets out the results from the FMM regressions, with OLS coefficients given for comparison. In each case, column 1 fits EDIV alone, column 2 FDIV alone and column 3 both together. The top panel fits the linear diversity measure. Recall that pairwise correlations suggest positive links between DIV and business turnover. For ethnic diversity, these basic links survive adding controls, with the OLS coefficient of EDIV 1.070 significant at 5\% (column 3). By contrast, coefficients of FDIV are non-significant. A 10\% increase in EDIV thus implies a 10.7\% 
rise in turnover. For a firm in turnover band 3 (midpoint $£ 250 \mathrm{k}$ ), this equates to a rise in turnover of $£ 26,750$.

\section{Table 4 about here}

As in Ozgen and De Graaff (2013) the FMM results are also substantially different from those in the pooled sample, highlighting the importance of controlling for unobservables. Coefficients of EDIV shift depending on the model fitted; in the fullest specification (column 3) we find a strong positive link for C1 firms (1.706) and a much smaller link for C3 (0.180), both significant at 1\%. Coefficients of FDIV are consistently positive for C3 (0.219 in the fullest model, significant at 1\%), but are unstable for C1 and C2.

The bottom panel of Table 5 adds the diversity dummy to proxy for non-linearity. Here, EDIV becomes non-significant in the OLS results. By contrast, FDIV results strongly suggest an Nshaped relationship rather than a linear link. The FMM approach disentangles some of the underlying linkages. For EDIV, C3 firms show signs of a U-shaped relationship, significant at 1\%. Specifically, results from the fullest model (column 6) suggest that for C3 firms, an ethnically diverse TMT is linked to a 0.984 percentage point drop in turnover compared to a homogenous firm, equivalent to a $£ 738$ drop for the average C3 business (whose average turnover band has a midpoint of $£ 75,000$ ). However, a $10 \%$ rise in TMT diversity after this brings a 15.83\% rise in turnover, worth approximately £11,800 to a C3 firm. This U-shape relationship is much weaker for C1 and C2 firms, with the former showing non-significant 
coefficients of EDIV when fitted alone (column 4) and a linear relationship when fitted with FDIV (column 6).

For gender diversity, the results suggest that the N-shape link exists for C2 and C3 firms, but not for C1. Table A1.3 explores this further by fitting a quadratic model. This confirms a significant N-shape link for C2 and C3 firms, significant at 1\%, although coefficients on the quadratic blow up a little. Turning points are respectively 0.10 and 0.11 on the folded diversity measure, which corresponds to underlying female TMT shares of $20 \%$ and $21 \%$. For C1 firms, coefficient point to an $\mathrm{N}$-shape relationship but are not significant.

Overall, we see that different 'diversities' have varying relationships to firms' turnover, and to each other. Pooled results also hide substantial differences in size and sign between groups of firms. C1 firms, the largest and most established, have a positive linear link from ethnic TMT diversity to turnover, but show no gender TMT links. C2 firms show no ethnicity links but an Nshaped relationship for gender. C3 firms, the smallest, most financial services-based and most London-centric group, show positive linear linkages on both ethnicity and gender, and also show some evidence of non-linear relationships (U-shaped for ethnicity, N-shaped for gender).

\subsection{Robustness checks}

Table 5 runs through a series of robustness checks. Main FMM results are provided in Column 1 for reference: OLS results are available on request. 


\section{Table 5 about here}

First, Column 2 removes London observations from the model (around 5.6\% of all observations). While OLS coefficients barely change, FMM results shift substantially with particularly large shifts in size and sign for EDIV coefficients. Taken at face value, this suggests that for firms in a given class, TMT ethnic diversity plays in opposite directions depending whether or not they are located in the capital or not. Section 8 explores this further by looking at the interaction of TMTlevel diversity with area type and demographics.

The NBS does not contain information on firm-level human capital, which is a potentially important omitted variable in equation (2). Columns 3 and 4 fit alternative area-level human capital measures taken from the UK Annual Population Survey. As expected, these shift coefficients of EDIV and FDIV, but the overall distribution of results remains the same.

Next, Column 5 fits additional controls for innovative activity, specifically whether firms expect to invest in $R \& D$, have university-industry links or use professional networks. Including these controls changes the main results, but on a much smaller and sample - so direct comparisons are hard. Column 6 includes the banded share of exports, reflecting the well-known link between exporting and firm performance (Wagner, 2007). Coefficients of EDIV are reduced for C1 and

C3 firms, becoming insignificant in the latter case. By contrast, FDIV becomes significant for C2 firms. Other research shows positive connections between diversity and trade, so the latter may be an intervening variable in diversity-turnover links (Docquier and Rapoport, 2012). Here, regressing exports on EDIV turns up an OLS coefficient of 1.091, significant at 5\%; for imports 
this is 1.012 , significant at $10 \%$ (for gender diversity, links is non-significant). For both innovation and exports, then, the analysis raises broader questions about the linkages between diversity, innovation, trade and business performance that need to be addressed further in other research.

Finally, I re-run equation (2) using two-way clustering on standard errors to deal with error correlation across (non-nested) industries and geographies. Following techniques developed by Cameron et al (2011), Table A1.4 compares OLS estimates with and without two-way clustering. Results barely change, suggesting that local industry shocks are not driving the main findings.

\section{Extensions}

\subsection{Ethnic diversity, firms and cities}

As discussed in section 2, in theory urban location might amplify links from firm-level ethnic diversity to business performance, through urban demographics and/or the productivityenhancing role of cities. For this data, the robustness checks in Section 7 certainly suggest that London location shapes overall results.

I use the Eurostat city-regional typology to explore these issues further. First, I fit dummies for capital city-region and second-tier city-region location, and interact these with TMT ethnic diversity in equation (2). With lagged area-level demographics in the controls vector, this 
specification should highlight any productivity-enhancing role of urban areas. Results for London and surrounds are set out in Table 6 (top panel).

\section{Table 6 about here}

OLS results show a positive significant effect of capital city location (column 1). Notably, for C3 firms this is negative significant, and turns EDIV negative too. Fitting the interaction shows a partial effect of 1.926 in the OLS, significant at 10\% (column 2). This appears to be driven by C3 firms, where the partial effect is 1.075, again significant at 10\%. For these firms, the total effect of EDIV is 1.207, and is increasing in capital city-region location, versus 0.132 for C3 firms in other city-regions; this suggests some amplifying effect of London and surrounds for these businesses, but the link is relatively weak.

Next, I make a three-way interaction between TMT diversity, lagged area-level diversity and urban type. Results are shown in the bottom panel. Comparing the size/sign of these partial and total effects with the previous estimates helps test whether urban demography also plays a role in city 'effects'. OLS results give an insignificant partial effect of EDIV, and a total effect driven by TMT diversity rather than area-level characteristics. By contrast, FMM results show partial effects for C2 and C3 firms significant at 1\%, with a total effect of EDIV for C3 businesses that is increasing in location as before. In this case, the total effect of EDIV in the London city region (EDIV*location*demography) is smaller than EDIV*location alone (0.66 vs. 1.207) but more robust (1\% vs. $10 \%$ significant). 
In Table A1.5, I re-run these regressions for second tier metro city-regions. Here, partial effects are interpreted as the relative 'effect' of EDIV in a second tier location, relative to all other locations (including the capital and surrounds). As before, the top panel shows the EDIV*location interaction, and the bottom panel shows EDIV*location*demography. Partial effects of EDIV*location are negative and non-significant in the OLS, weakly positive significant for C1 firms and non-significant for C2 and C3 firms. Overall, and in all FMM classes, total effects of EDIV are decreasing in second-tier cities - in clear contrast to the capital city-region results.

For EDIV*location*demography, partial effects are positive significant for C3 firms, and nonsignificant for other classes and OLS results. As with diversity-location interaction, total effects are always decreasing in second tier locations. Alternative specifications using a combined capital and second-tier city-region location dummy also find declining total effects of EDIV for C2 and C3 firms (results are available on request). Together, these results suggest that secondtier locations lack the amplifying effects on firm diversity present in the London city-region, either through agglomeration economies or demography.

Overall, these results suggest that firm-level diversity-turnover links are amplified in the London city-region, but not in other metros; that both agglomeration economies and demographics play a role; and that 'effects' are driven by C3 firms, which are smallest, youngest and most serviceorientated (and most London-based). This is consistent with the 'nursery cities' hypothesis that smaller, younger firms benefit most from big city learning effects (Jacobs, 1961; Duranton and 
Puga, 2001). These results are also consistent with Trax et al (2012), who find that area-level diversity is at least as important to firm performance as internal workforce composition.

\subsection{Homogeneity analysis}

As a final extension of the analysis, I re-run equation (2) using dummies for homogenous TMTs instead of the linear diversity measure. Specifically, for ethnicity I fit dummies for all-majority and all-minority TMTs; and for gender, all-male/female TMTs. In both cases associations are interpreted as the relative 'effect' of that TMT composition versus diverse firms. As discussed in Section 3, this approach helps uncover the kind of homogeneity linked to turnover, and what homogeneity payoffs / penalties might exist. Results are given in Table A1.6: the top panel looks at ethnicity and the bottom panel gender.

Pairwise correlations in Table A1.1 suggest negative links from all-minority and all-female TMTs to turnover in the pooled sample. These hold up in the OLS analysis: I also find smaller, negative significant links from all-majority TMTs, but there is a non-significant and close to zero link from all-male TMTs. A priori, penalties from 'lock-in’ should be similar for all homogenous groups, so that the larger penalties against all-minority and all-female headed firms imply the

presence of external discrimination. However, the FMM analysis suggests some important within-sample differences. For ethnicity, C1 and C3 firms show similar results to the OLS, but C2 firms suggest positive links from homogeneity to turnover, which are $1 \%$ significant for allminority TMTs. For gender, C1 firms show positive links from all-male TMTs; C2 firms replicate OLS results; while for C3 firms, all-male penalties are larger than all-female. 


\section{Discussion}

This paper examines some current hot issues in the 'economics of diversity': firm-level links from diversity to business performance, and the interaction of firm and area-level characteristics, especially urban location. Unusually, my data allows me to focus the analysis on firms' 'top teams', who play a crucial role in setting the strategic direction of the business, and compares ethnic and gender diversity in the TMT. It is one of very few studies to do this. I also use latent class analysis to handle firm-level unobservables. This leads to substantial improvements in identification over OLS results, and highlights significant differences between groups of firms.

Overall, I find that ethnic and gender TMT diversity have varying relationships to firm turnover across firm classes, and relative to each other. The largest and most established firms in my data show a linear link from ethnic diversity to revenue; other groups, predominantly smaller and less formalised in working structures, seem to have non-linear relationships (U-shape for ethnic diversity, N-shape for gender). These hold most clearly for a group of the smallest, youngest, financial services and London-centric firms. This group also shows strong positive linear links from TMT ethnic and gender diversity. Strikingly, firms in this group based in London show some signs of amplified ethnic diversity linkages, via big city agglomeration economies and urban demography. By contrast, second tier metro locations exhibit decreasing effects.

There are some important caveats on these results. First, and crucially, my data is cross-sectional and so I am unable to control for firm-level selection effects. This means that the direction of causation is not clear, and results have to read purely as associations. This is common to firm- 
level analysis of this kind: causation is very challenging to pin down (Adams et al., 2010). Second, the unavoidable banding of the outcome variable in the dataset reduces the precision of my estimates, and some controls are handled using workarounds.

As such, the analysis leaves a number of areas for further work. Worker-firm panel data, which is hard to construct in the UK, would substantially improve future research - not least by allowing researchers to test build and decay effects of diversity over time. More challenging is to find exogenous shifters of workforce or TMT composition. These occur rarely (see Ahern and Dittmer (2012) for one example), so researchers tend to rely on lab studies or instruments. The external validity of the former is moot, especially given the urban context issues examined here. However, lab studies do highlight the importance of task and organisational context, which also appear to condition the impacts of group and firm demographics (Mannix and Neale, 2005). Similarly, gender / culture-specific individual preferences may also impact performance at the team level in ways that are hard to untangle in real world scenarios (Azmat and Petrongolo, Forthcoming). In situ research at this level has been largely qualitative to date. Structured, largescale analysis would be a major step forward. 
Figures and tables

Figure 1: Kernel density of banded turnover.

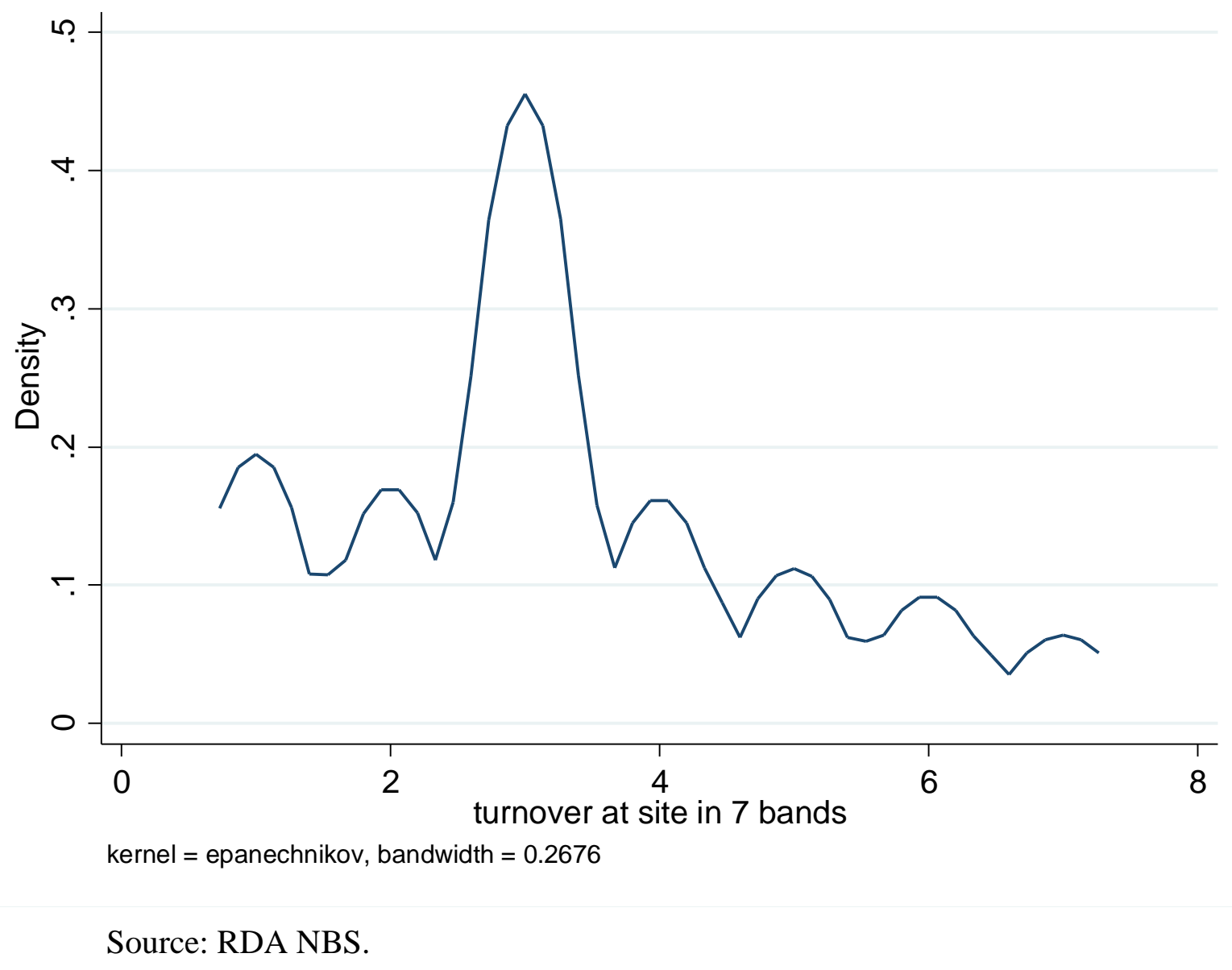


Table 1. Summary statistics.

\begin{tabular}{|c|c|c|c|c|c|}
\hline VARIABLES & $\mathbf{N}$ & Mean & SD & Min & Max \\
\hline Turnover at site in 7 bands & 2,381 & 3.297 & 1.628 & 1 & 7 \\
\hline \% Minority ethnic TMT & 2,381 & 0.0347 & 0.172 & 0 & 1 \\
\hline \% Minority ethnic TMT folded & 2,381 & 0.007 & 0.055 & 0 & 0.5 \\
\hline Minority ethnic-headed firm & 2,381 & 0.028 & 0.164 & 0 & 1 \\
\hline$\%$ Female TMT & 2,381 & 0.255 & 0.334 & 0 & 1 \\
\hline \% Female TMT folded & 2,381 & 0.148 & 0.218 & 0 & 0.5 \\
\hline All-female TMT & 2,381 & 0.101 & 0.302 & 0 & 1 \\
\hline $\begin{array}{l}\text { No of employees who receive a salary } \\
\text { (excluding owners) }\end{array}$ & 2,381 & 20.17 & 244.5 & 0 & 12,435 \\
\hline Number of owners/partners/directors & 2,381 & 2.096 & 3.676 & 1 & 100 \\
\hline Years business in operation & 2,381 & 3.397 & 0.858 & 1 & 4 \\
\hline Firm is subsidiary of UK parent & 2,381 & 0.0326 & 0.178 & 0 & 1 \\
\hline Firm is subsidiary of foreign parent & 2,381 & 0.0151 & 0.122 & 0 & 1 \\
\hline Firm is ultimate holding company & 2,381 & 0.0138 & 0.117 & 0 & 1 \\
\hline Firm is independent & 2,381 & 0.733 & 0.442 & 0 & 1 \\
\hline Firm is LLP & 2,381 & 0.134 & 0.340 & 0 & 1 \\
\hline Share of foreign sales banded & 2,381 & 0.696 & 1.444 & 0 & 6 \\
\hline Share of foreign inputs banded & 2,381 & 1.018 & 1.804 & 0 & 6 \\
\hline Growth plan dummy & 2,381 & 0.320 & 0.467 & 0 & 1 \\
\hline Business is operating below capacity & 2,381 & 0.675 & 0.468 & 0 & 1 \\
\hline Hard-to-fill vacancies in past 12 months & 2,381 & 1.813 & 0.390 & 1 & 2 \\
\hline $\begin{array}{l}\text { Business provided some training in past } 12 \\
\text { months }\end{array}$ & 2,381 & 0.331 & 0.471 & 0 & 1 \\
\hline $\begin{array}{l}\text { Product or process innovation in last } 12 \\
\text { months }\end{array}$ & 2,381 & 0.244 & 0.429 & 0 & 1 \\
\hline $\begin{array}{l}\text { Firm expects to do R\&D investment in next } 12 \\
\text { months }\end{array}$ & 2,381 & 0.621 & 0.485 & 0 & 1 \\
\hline Business uses U-I links for R\&D & 1,718 & 0.196 & 0.397 & 0 & 1 \\
\hline Business uses specialist networks for info & 2,152 & 0.416 & 0.493 & 0 & 1 \\
\hline Ln(population density, 2001) & 2,381 & 6.040 & 1.269 & 3.116 & 9.116 \\
\hline $\begin{array}{l}\text { Five year lag of area minority ethnic working } \\
\text { age population }\end{array}$ & 2,381 & 7.032 & 9.095 & 0.500 & 41.75 \\
\hline
\end{tabular}

Source: RDA NBS. 
Table 2. Three-component FMM performance.

\begin{tabular}{|c|c|c|c|}
\hline Component & C1 & C2 & C3 \\
\hline Frequency & 686 & 1386 & 309 \\
\hline Percent & 28.81 & 58.21 & 12.98 \\
\hline \multirow{2}{*}{ Mean posterior probability } & \multicolumn{3}{|c|}{ Most likely latent class / component } \\
\hline & C1 & $\mathrm{C} 2$ & C3 \\
\hline p1 & 0.887 & 0.103 & 0.01 \\
\hline p2 & 0.253 & 0.729 & 0.018 \\
\hline p3 & 0.153 & 0.096 & 0.751 \\
\hline Entropy & & 0.574 & \\
\hline AIC & & 7039.985 & \\
\hline BIC & & 8021.782 & \\
\hline Sample size adjusted BIC & & 7481.656 & \\
\hline \# free parameters & & 170 & \\
\hline Log likelihood & & -3349.993 & \\
\hline
\end{tabular}

Source: RDA NBS. 
Table 3. FMM components: descriptive analysis.

\begin{tabular}{|c|c|c|c|c|c|}
\hline \multirow[b]{2}{*}{ Characteristic } & \multicolumn{5}{|c|}{ Percentage of firms } \\
\hline & All & Comp 1 & Comp 2 & Comp 3 & $\begin{array}{c}\text { C1-3 } \\
\text { weighted }\end{array}$ \\
\hline Turnover at site in 7 bands & 3.297 & 4.491 & 3.124 & 1.913 & 3.176 \\
\hline \% minority ethnic TMT & 0.0347 & 0.034 & 0.035 & 0.048 & 0.039 \\
\hline$\%$ minority ethnic TMT folded & 0.007 & 0.014 & 0.006 & 0.015 & 0.012 \\
\hline All minority-ethnic TMT & 0.0275 & 0.020 & 0.029 & 0.045 & 0.032 \\
\hline \% Female owners/partners/directors & 0.255 & 0.246 & 0.259 & 0.276 & 0.260 \\
\hline$\%$ female TMT folded & 0.148 & 0.144 & 0.154 & 0.144 & 0.147 \\
\hline All-female TMT & 0.101 & 0.085 & 0.096 & 0.146 & 0.109 \\
\hline No of employees who receive a salary & 20.17 & 62.67 & 7.25 & 4.38 & 24.77 \\
\hline Number of owners/partners/directors & 2.096 & 2.376 & 2.085 & 2.003 & 2.155 \\
\hline Years business in operation & 3.397 & 3.478 & 3.387 & 3.269 & 3.378 \\
\hline Firm is subsidiary of UK parent & 0.0326 & 0.051 & 0.028 & 0.023 & 0.034 \\
\hline Firm is subsidiary of foreign parent & 0.0151 & 0.028 & 0.010 & 0.013 & 0.017 \\
\hline Firm is ultimate holding company & 0.0138 & 0.028 & 0.011 & 0.013 & 0.017 \\
\hline Firm is independent & 0.733 & 0.726 & 0.741 & 0.761 & 0.743 \\
\hline Firm is LLP & 0.134 & 0.118 & 0.149 & 0.091 & 0.119 \\
\hline Share of foreign inputs banded & 1.018 & 1.108 & 0.911 & 0.906 & 0.975 \\
\hline Growth plan dummy & 0.320 & 0.443 & 0.310 & 0.265 & 0.339 \\
\hline Business is operating below capacity & 0.675 & 0.687 & 0.665 & 0.715 & 0.689 \\
\hline Hard-to-fill vacancies in past 12 months & 1.813 & 1.748 & 1.832 & 1.867 & 1.816 \\
\hline Business provided some training & 0.331 & 0.459 & 0.322 & 0.262 & 0.348 \\
\hline Product or process innovation & 0.244 & 0.294 & 0.237 & 0.275 & 0.269 \\
\hline Firm expects to do R\&D investment & 0.621 & 0.685 & 0.617 & 0.599 & 0.634 \\
\hline Business uses U-I links for R\&D & 0.196 & 0.255 & 0.161 & 0.164 & 0.193 \\
\hline Business uses specialist networks for info & 0.416 & 0.453 & 0.409 & 0.410 & 0.424 \\
\hline Primary (a-c) & 2.45 & 1.60 & 2.45 & 3.56 & 2.35 \\
\hline Manufacturing (d-e) & 12.5 & 15.31 & 11.54 & 11.97 & 12.68 \\
\hline Construction (f) & 8.7 & 7.14 & 8.51 & 7.77 & 8.02 \\
\hline Distribution (g) & 22.3 & 23.18 & 20.92 & 16.83 & 21.04 \\
\hline Hotels/catering (h) & 6.52 & 4.23 & 6.93 & 9.39 & 6.47 \\
\hline Transport/storage/comms (i) & 3.66 & 3.79 & 3.82 & 2.91 & 3.70 \\
\hline Financial intermediation (j-k) & 35.04 & 32.22 & 37.95 & 42.72 & 36.92 \\
\hline Public/personal services (l-o) & 8.83 & 12.54 & 7.86 & 4.85 & 8.82 \\
\hline Capital city region & 13.77 & 15.31 & 15.44 & 14.24 & 15.25 \\
\hline Second tier metro region & 20.02 & 24.93 & 21.72 & 21.36 & 22.60 \\
\hline Smaller metro region & 29.12 & 27.99 & 27.92 & 30.42 & 28.26 \\
\hline Other regions & 37.08 & 31.78 & 34.92 & 33.98 & 33.89 \\
\hline Observations & 2381 & 686 & 1386 & 309 & 2381 \\
\hline
\end{tabular}

Source: RDA NBS. 
Table 4. Diversity and business turnover. Main results.

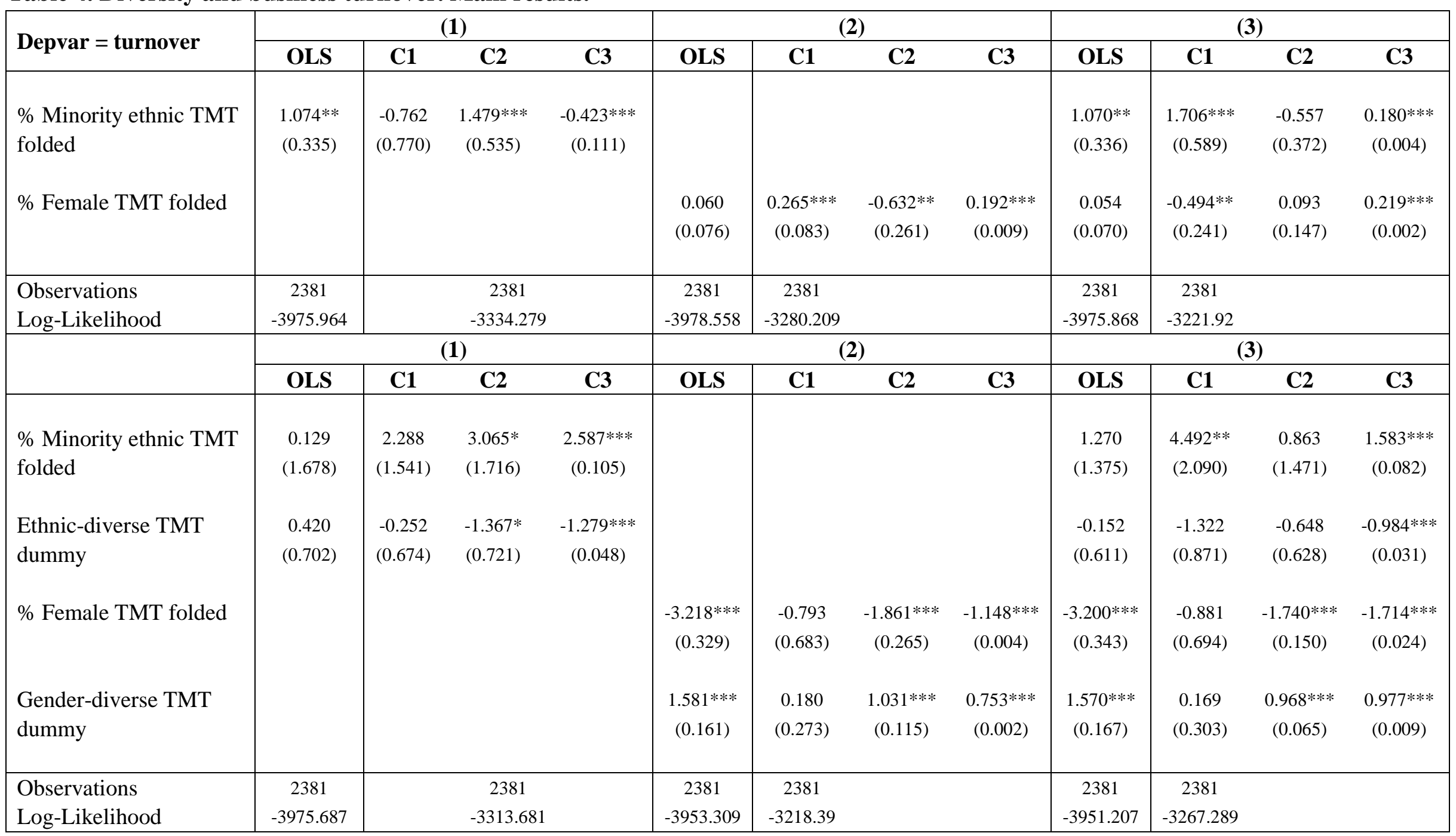

\section{Source: RDA NBS.}

Note. Controls include top team size, firm age, firm employees, firm type dummies, whether firm has hard to fill vacancies; has a growth plan; has provided internal/external training; has innovated in the past year; is operating below capacity. Area controls are population density and minority ethnic working age population, lagged to 2001. All models use SIC1 and NUTS2 dummies. HAC standard errors clustered on SIC1. ${ }^{*} \mathrm{p}<0.1,{ }^{* *} \mathrm{p}<0.05,{ }^{* * *} \mathrm{p}<0.01$ 
Table 5. Robustness checks.

\begin{tabular}{|c|c|c|c|c|c|c|}
\hline \multirow{2}{*}{$\begin{array}{l}\text { Dependent variable } \\
=\text { turnover }\end{array}$} & \multicolumn{3}{|c|}{ (1) } & \multicolumn{3}{|c|}{ (2) } \\
\hline & C1 & $\mathrm{C} 2$ & C3 & C1 & C2 & C3 \\
\hline \% Minority ethnic TMT folded & $\begin{array}{c}1.706 * * * \\
(0.589)\end{array}$ & $\begin{array}{l}-0.557 \\
(0.372)\end{array}$ & $\begin{array}{c}0.180^{* * *} \\
(0.004)\end{array}$ & $\begin{array}{l}-0.266 \\
(0.615)\end{array}$ & $\begin{array}{c}2.004 * * * \\
(0.629)\end{array}$ & $\begin{array}{c}-0.691 * * * \\
(0.010)\end{array}$ \\
\hline \% Female TMT folded & $\begin{array}{c}-0.494^{* *} \\
(0.241)\end{array}$ & $\begin{array}{c}0.093 \\
(0.147)\end{array}$ & $\begin{array}{c}0.219^{* * *} \\
(0.002)\end{array}$ & $\begin{array}{l}0.214^{*} \\
(0.118)\end{array}$ & $\begin{array}{c}-0.586 * * * \\
(0.191)\end{array}$ & $\begin{array}{c}0.429^{* * *} \\
(0.003)\end{array}$ \\
\hline London & $\mathrm{Y}$ & $\mathrm{Y}$ & $\mathrm{Y}$ & $\mathrm{N}$ & $\mathrm{N}$ & $\mathrm{N}$ \\
\hline \multirow[t]{3}{*}{$\begin{array}{l}\text { Observations } \\
\text { Log-likelihood }\end{array}$} & \multicolumn{3}{|c|}{$\begin{array}{c}2381 \\
-3221.920\end{array}$} & \multicolumn{3}{|c|}{$\begin{array}{c}2248 \\
-3060192\end{array}$} \\
\hline & \multicolumn{3}{|c|}{ (3) } & \multicolumn{3}{|c|}{ (4) } \\
\hline & C1 & C2 & C3 & C1 & C2 & C3 \\
\hline \% Minority ethnic TMT folded & $\begin{array}{c}1.886^{* * *} \\
(0.675)\end{array}$ & $\begin{array}{l}-0.124 \\
(0.378)\end{array}$ & $\begin{array}{c}0.151^{* * *} \\
(0.045)\end{array}$ & $\begin{array}{c}1.987^{* * *} \\
(0.751)\end{array}$ & $\begin{array}{l}-0.100 \\
(0.519)\end{array}$ & $\begin{array}{c}0.059^{* * *} \\
(0.002)\end{array}$ \\
\hline \% Female TMT folded & $\begin{array}{c}-0.710^{* * *} \\
(0.228)\end{array}$ & $\begin{array}{c}0.301 \\
(0.200)\end{array}$ & $\begin{array}{c}0.350^{* * *} \\
(0.082)\end{array}$ & $\begin{array}{c}-0.592 * * \\
(0.233)\end{array}$ & $\begin{array}{l}0.258^{*} \\
(0.138)\end{array}$ & $\begin{array}{c}0.243^{* * *} \\
(0.001)\end{array}$ \\
\hline \% Area professionals & $\mathrm{Y}$ & $\mathrm{Y}$ & $\mathrm{Y}$ & $\mathrm{N}$ & $\mathrm{N}$ & $\mathrm{N}$ \\
\hline \% Area NVQ4 & $\mathrm{N}$ & $\mathrm{N}$ & $\mathrm{N}$ & $\mathrm{Y}$ & $\mathrm{Y}$ & $\mathrm{Y}$ \\
\hline \multirow[t]{3}{*}{$\begin{array}{l}\text { Observations } \\
\text { Log-likelihood }\end{array}$} & \multicolumn{3}{|c|}{$\begin{array}{c}2104 \\
-2899.036\end{array}$} & \multicolumn{3}{|c|}{$\begin{array}{c}2104 \\
-2816.278\end{array}$} \\
\hline & \multicolumn{3}{|c|}{ (5) } & \multicolumn{3}{|c|}{ (6) } \\
\hline & C1 & C2 & C3 & C1 & $\mathrm{C} 2$ & C3 \\
\hline \% Minority ethnic TMT folded & $\begin{array}{l}2.011^{* *} \\
(0.855)\end{array}$ & $\begin{array}{l}-0.581 \\
(0.411)\end{array}$ & $\begin{array}{c}-0.483^{* * *} \\
(0.001)\end{array}$ & $\begin{array}{c}1.212^{* * *} \\
(0.460)\end{array}$ & $\begin{array}{l}-0.442 \\
(0.333)\end{array}$ & $\begin{array}{c}0.016 \\
(0.023)\end{array}$ \\
\hline \% Female TMT folded & $\begin{array}{c}0.115 \\
(0.274)\end{array}$ & $\begin{array}{c}0.169 \\
(0.161)\end{array}$ & $\begin{array}{c}-0.376^{* * *} \\
(0.000)\end{array}$ & $\begin{array}{c}-0.412 * * * \\
(0.102)\end{array}$ & $\begin{array}{c}0.195^{* * *} \\
(0.065)\end{array}$ & $\begin{array}{c}0.137^{* * *} \\
(0.003)\end{array}$ \\
\hline Innovation controls & $\mathrm{Y}$ & $\mathrm{Y}$ & $\mathrm{Y}$ & $\mathrm{N}$ & $\mathrm{N}$ & $\mathrm{N}$ \\
\hline \% International sales & $\mathrm{N}$ & $\mathrm{N}$ & $\mathrm{N}$ & $\mathrm{Y}$ & $\mathrm{Y}$ & $\mathrm{Y}$ \\
\hline $\begin{array}{l}\text { Observations } \\
\text { Log-likelihood }\end{array}$ & \multicolumn{3}{|c|}{$\begin{array}{c}1284 \\
-1586.153\end{array}$} & \multicolumn{3}{|c|}{$\begin{array}{c}2381 \\
-3232515\end{array}$} \\
\hline
\end{tabular}

Source: RDA NBS.

Note. Controls as in Table 4. All models use SIC1 and NUTS2 dummies. HAC standard errors clustered on SIC1. ${ }^{*} \mathrm{p}<0.1,{ }^{* *} \mathrm{p}<0.05,{ }^{* * *} \mathrm{p}<0.01$ 
Table 6. Ethnic diversity: linking firms, capital city-regions and urban demographics.

\begin{tabular}{|c|c|c|c|c|c|c|c|c|}
\hline \multirow{2}{*}{ Dependent variable $=$ turnover } & \multicolumn{4}{|c|}{ (1) } & \multicolumn{4}{|c|}{$(2)$} \\
\hline & OLS & C1 & $\mathrm{C} 2$ & C3 & OLS & C1 & C2 & C3 \\
\hline \% Minority ethnic TMT folded & $\begin{array}{l}1.088 * * \\
(0.327)\end{array}$ & $\begin{array}{l}1.513^{* *} \\
(0.624)\end{array}$ & $\begin{array}{l}-0.408 \\
(0.256)\end{array}$ & $\begin{array}{c}-0.573 * * * \\
(0.003)\end{array}$ & $\begin{array}{c}0.546 \\
(0.460)\end{array}$ & $\begin{array}{l}-0.150 \\
(0.691)\end{array}$ & $\begin{array}{c}0.578 \\
(0.383)\end{array}$ & $\begin{array}{c}0.132 \\
(0.228)\end{array}$ \\
\hline $\begin{array}{l}\text { \% Minority ethnic TMT * } \\
\text { capital city region }\end{array}$ & & & & & $\begin{array}{l}1.962 * \\
(0.981)\end{array}$ & $\begin{array}{c}0.447 \\
(0.640)\end{array}$ & $\begin{array}{c}1.926 \\
(1.539)\end{array}$ & $\begin{array}{l}1.075^{*} \\
(0.567)\end{array}$ \\
\hline Capital city region & $\begin{array}{l}0.230 * \\
(0.114)\end{array}$ & $\begin{array}{c}0.131 \\
(0.227)\end{array}$ & $\begin{array}{c}0.114 \\
(0.094)\end{array}$ & $\begin{array}{c}-0.182 * * * \\
(0.001)\end{array}$ & $\begin{array}{l}0.207^{*} \\
(0.103)\end{array}$ & $\begin{array}{c}0.103 \\
(0.128)\end{array}$ & $\begin{array}{c}0.129 \\
(0.289)\end{array}$ & $\begin{array}{l}-0.024 \\
(0.114)\end{array}$ \\
\hline \multirow[t]{3}{*}{$\begin{array}{l}\text { Observations } \\
\text { Log-Likelihood }\end{array}$} & $\begin{array}{c}2381 \\
-3975.198 \\
\end{array}$ & \multicolumn{3}{|c|}{$\begin{array}{c}2381 \\
-3240.064 \\
\end{array}$} & $\begin{array}{c}2381 \\
-3973.387 \\
\end{array}$ & \multicolumn{3}{|c|}{$\begin{array}{c}2381 \\
-3323.053 \\
\end{array}$} \\
\hline & \multicolumn{4}{|c|}{ (3) } & \multicolumn{4}{|c|}{ (4) } \\
\hline & OLS & C1 & $\mathrm{C} 2$ & C3 & OLS & C1 & $\mathrm{C2}$ & C3 \\
\hline \% Minority ethnic TMT folded & $\begin{array}{l}1.088 * * \\
(0.327)\end{array}$ & $\begin{array}{l}1.513^{* *} \\
(0.624)\end{array}$ & $\begin{array}{l}-0.408 \\
(0.256)\end{array}$ & $\begin{array}{c}-0.573 * * * \\
(0.003)\end{array}$ & $\begin{array}{c}0.853 * * \\
(0.313)\end{array}$ & $\begin{array}{l}0.832 * * \\
(0.379)\end{array}$ & $\begin{array}{l}-0.302 \\
(0.582)\end{array}$ & $\begin{array}{c}0.093 \\
(0.093)\end{array}$ \\
\hline $\begin{array}{l}\text { TMT * capital CR * } \\
\text { lagged minority population }\end{array}$ & & & & & $\begin{array}{c}0.048 \\
(0.026)\end{array}$ & $\begin{array}{l}-0.057 \\
(0.047)\end{array}$ & $\begin{array}{c}0.767 * * * \\
(0.143)\end{array}$ & $\begin{array}{c}0.567 * * * \\
(0.011)\end{array}$ \\
\hline Capital city region & $\begin{array}{l}0.230^{*} \\
(0.114)\end{array}$ & $\begin{array}{c}0.131 \\
(0.227)\end{array}$ & $\begin{array}{c}0.114 \\
(0.094)\end{array}$ & $\begin{array}{c}-0.182 * * * \\
(0.001)\end{array}$ & $\begin{array}{l}0.223^{*} \\
(0.113)\end{array}$ & $\begin{array}{c}0.151 \\
(0.228)\end{array}$ & $\begin{array}{c}0.162 \\
(0.138)\end{array}$ & $\begin{array}{l}-0.037 \\
(0.030)\end{array}$ \\
\hline $\begin{array}{l}\text { Five year lag of area minority } \\
\text { ethnic working age population }\end{array}$ & $\begin{array}{c}0.000 \\
(0.003)\end{array}$ & $\begin{array}{l}-0.002 \\
(0.012)\end{array}$ & $\begin{array}{c}0.004 \\
(0.003)\end{array}$ & $\begin{array}{c}0.007^{* * *} \\
(0.000)\end{array}$ & $\begin{array}{c}0.000 \\
(0.003)\end{array}$ & $\begin{array}{c}0.002 \\
(0.009)\end{array}$ & $\begin{array}{l}0.008^{*} \\
(0.004)\end{array}$ & $\begin{array}{c}0.002 \\
(0.001)\end{array}$ \\
\hline $\begin{array}{l}\text { Observations } \\
\text { Log-Likelihood }\end{array}$ & $\begin{array}{c}2381 \\
-3975.198 \\
\end{array}$ & & $\begin{array}{c}2381 \\
-3240.064\end{array}$ & & $\begin{array}{c}2381 \\
-3974.582 \\
\end{array}$ & & $\begin{array}{c}2381 \\
-3332.470 \\
\end{array}$ & \\
\hline
\end{tabular}

Source: RDA NBS.

Note. Controls as in Table 4. All models use SIC1 and NUTS2 dummies. HAC standard errors clustered on SIC1.

$* \mathrm{p}<0.1, * * \mathrm{p}<0.05, * * * \mathrm{p}<0.01$. 


\section{References}

Adams R, B., Hermalin BE and Weisbach MS. (2010) The Role of Boards of Directors in Corporate Governance: A Conceptual Framework and Survey. Journal of Economic Literature 48: 58-107.

Ahern KR and Dittmar AK. (2012) The changing of the boards: The impact on firm valuation of mandated female board representation. The Quarterly Journal of Economics 127: 137197.

Alesina A and Ferrara EL. (2005) Ethnic Diversity and Economic Performance. Journal of Economic Literature 43: 762-800.

Angrist J and Pischke J-S. (2009) Mostly Harmless Econometrics, Princeton: Princeton University Press.

Apesteguia J, Azmat G and Iriberri N. (2012) The Impact of Gender Composition on Team Performance and Decision-Making: Evidence from the field. Management Science 58: 78-93.

Ashraf Q and Galor O. (2013) The 'Out of Africa' Hypothesis, Human Genetic Diversity, and Comparative Economic Development. American Economic Review 103: 1-46.

Azmat G and Petrongolo B. (Forthcoming) Gender and the Labor Market: What Have We Learned from Field and Lab Experiments? Labour Economics.

Baum-Snow N and Pavan R. (2012) Understanding the City Size Wage Gap. The Review of Economic Studies 79: 88-127.

Brown S, Greene W and Harris MN. (2014) A New Formulation for Latent Class Models. IZA Discussion Paper 8283. Bonn: IZA.

Cameron AC, Gelbach JB and Miller DL. (2011) Robust Inference With Multiway Clustering. Journal of Business \& Economic Statistics 29: 238-249.

Card D. (2010) How Immigration Affects US Cities. In: Inman RP (ed) Making Cities Work: Prospects and Policies for Urban America. Princeton: Princeton University Press, 158200.

Certo ST, Lester RH, Dalton CM, et al. (2006) Top Management Teams, Strategy and Financial Performance: A Meta-Analytic Examination. Journal of Management Studies 43: 813839.

Collier P. (2013) Exodus: How migration is changing our world, Oxford: OUP.

Deb P. (2008) Finite Mixture Models. New York: Hunter College / CUNY.

Delfgaauw J, Dur R, Sol J, et al. (2013) Tournament Incentives in the Field: Gender Differences in the Workplace. Journal of Labor Economics 31: 305-326.

Docquier F and Rapoport H. (2012) Globalization, Brain Drain, and Development. Journal of Economic Literature 50: 681-730.

Duranton G and Puga D. (2001) Nursery Cities: Urban Diversity, Process Innovation and the Life Cycle of Products. American Economic Review 91: 1454-1477.

Florida R. (2002) The Rise of the Creative Class, New York: Basic Books.

Foley CF and Kerr WR. (2013) Ethnic Innovation and U.S. Multinational Firm Activity. Management Science 59: 1529-1544.

Gilroy P. (2004) After Empire: Melancholia or Convivial Culture?, Abingdon: Routledge. 
Goodhart D. (2013) The British Dream: Success and Failures of Post-War Immigration London: Atlantic.

Haltiwanger J, Jarmin R, S. and Miranda J. (2013) Who Creates Jobs? Small versus Large versus Young. The Review of Economics and Statistics 95: 347-361.

Hambrick DC and Mason PA. (1984) Upper Echelons: The Organization as a Reflection of Its Top Managers. The Academy of Management Review 9: 193-206.

Hastie T, Tibshirani R and Friedman J. (2009) The Elements of Statistical Learning: Data mining, inference and prediction, Berlin: Springer.

Heckman J and Singer B. (1984) A Method for Minimizing the Impact of Distributional Assumptions in Econometric Models for Duration Data. Econometrica 52: 271-320.

Hoogendoorn S, Oosterbeek H and van Praag M. (2013) The Impact of Gender Diversity on the Performance of Business Teams: Evidence from a Field Experiment. Management Science 59: 1514-1528.

Ipsos MORI. (2009) The National Business Survey: National Report. London: Ipsos MORI. Jacobs J. (1961) The Life and Death of Great American Cities, London: Pimlico.

Javorcik BS. (2004) Does Foreign Direct Investment Increase the Productivity of Domestic Firms? In Search of Spillovers Through Backward Linkages. The American Economic Review 94: 605-627.

Kemeny T. (2014) Immigrant Diversity and Economic Performance in Cities. International Regional Science Review.

Kerr W, Kerr SP and Lincoln W. (2013) Skilled Immigration and the Employment Structures of U.S. Firms. Mimeo. Cambridge, Mass.: Harvard Business School.

Kerr WR. (2013) U.S. High-Skilled Immigration, Innovation, and Entrepreneurship: Empirical Approaches and Evidence. National Bureau of Economic Research Working Paper Series 19377. Cambridge, MA: NBER.

Lee N. (2014) Migrant and ethnic diversity, cities and innovation: Firm effects or city effects? Journal of Economic Geography.

Lewis E and Peri G. (Forthcoming) Immigration and the Economics of Cities and Regions. In: Duranton G, Henderson JV and Strange W (eds) Handbook of Regional and Urban Economics Volume 5. North Holland: Elsevier.

Mannix E and Neale MA. (2005) What Differences Make a Difference?: The Promise and Reality of Diverse Teams in Organizations. Psychological Science in the Public Interest 6: 31-55.

Maré DC and Fabling R. (2011) Productivity and Local Workforce Composition. Motu Working Paper 11-10. Wellington, NZ: Motu Economic and Public Policy Research.

Maré DC, Fabling R and Stillman S. (2013) Innovation and the local workforce. Papers in Regional Science: n/a-n/a.

Nathan M. (2012) After Florida: Towards an Economics of Diversity. European Urban and Regional Studies Online First.

Nathan M and Lee N. (2013) Cultural diversity, innovation and entrepreneurship: Firm-level evidence from London. Economic Geography 89: 367-394.

OECD. (2009) OECD Patent Statistics Manual. Paris: OECD. 
Ostergaard CR, Timmermans B and Kristinsson K. (2011) Does a different view create something new? The effect of employee diversity on innovation. Research Policy 40: 500-509.

Ottaviano G, Bellini E and Maglietta A. (2007) Diversity and the Creative Capacity of Cities and Regions. SUSDIV Paper 2.2007. Bologna: FEEM.

Ozgen C and De Graaff T. (2013) Sorting out the impact of cultural diversity on innovative firms. An empirical analysis of Dutch micro-data. Norface Discussion Paper Series 2013012. London: University College London.

Ozgen C, Nijkamp P and Poot J. (2013) The impact of cultural diversity on firm innovation: evidence from Dutch micro-data. IZA Journal of Migration 2: 18.

Page S. (2007) The Difference: How the Power of Diversity Creates Better Groups, Firms, Schools and Societies, Princeton: Princeton University Press.

Parrotta P, Pozzoli D and Pytlikova M. (2014a) Labor diversity and firm productivity. European Economic Review 66: 144-179.

Parrotta P, Pozzoli D and Pytlikova M. (2014b) The nexus between labor diversity and firm's innovation. Journal of Population Economics 27: 303-364.

Peri G. (2012) The Effect Of Immigration On Productivity: Evidence From U.S. States. Review of Economics and Statistics 94: 348-358.

Ramaswamy V, DeSarbo W, Reibstein D, et al. (1993) An empirical pooling approach for estimating marketing mix elasticities with PIMS data. Marketing Science 12.

Rosenthal S and Strange W. (2004) Evidence on the Nature and Sources of Agglomeration Economies. In: Henderson V and Thisse J-F (eds) Handbook of Urban and Regional Economics Volume 4. Amsterdam: Elsevier, 2119-2171.

Smith K. (2005) Measuring innovation. In: Fagerberg J, Mowery D and Nelson R (eds) The Oxford Handbook of Innovation. Oxford: Oxford University Press, 148-177.

Trax M, Brunow S and Suedekum J. (2012) Cultural Diversity and Plant-Level Productivity. IZA Discussion Paper 6845. Bonn: IZA.

Varian HR. (2014) Big Data: New Tricks for Econometrics. Journal of Economic Perspectives 28: 3-28.

Wagner J. (2007) Exports and Productivity: A Survey of the Evidence from Firm-level Data. World Economy 30: 60-82. 


\section{Appendix 1 / Additional results}

Table A1.1 Correlation matrix of main variables.

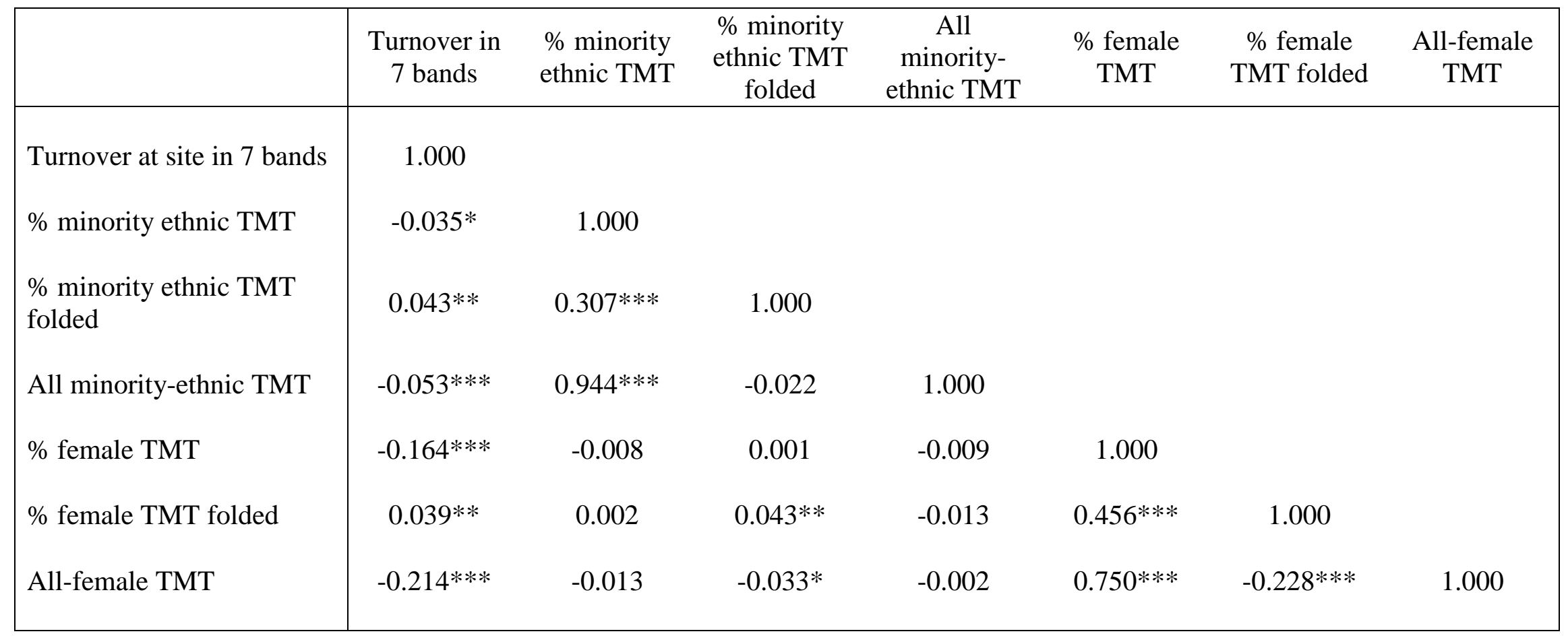

Source: RDA NBS.

Note: * = pairwise correlation significant at $10 \%, * * 5 \%, * * * 1 \%$ 
Table A1.2 Firm latent classes by NUTS2 region.

\begin{tabular}{|c|c|c|c|c|c|}
\hline \multirow[b]{2}{*}{ NUTS2 region } & \multicolumn{5}{|c|}{ Percentage of firms } \\
\hline & All & Comp 1 & Comp 2 & Comp 3 & $\begin{array}{c}C 1-3 \\
\text { weighted }\end{array}$ \\
\hline Tees valley and Durham & 2.01 & 2.04 & 2.24 & 1.62 & 2.10 \\
\hline Northumberland and Tyne and Wear & 2.71 & 3.5 & 2.53 & 2.27 & 2.78 \\
\hline Cumbria & 1.15 & 1.46 & 0.87 & 1.29 & 1.09 \\
\hline Cheshire & 1.56 & 1.46 & 1.59 & 1.62 & 1.56 \\
\hline Greater Manchester & 2.27 & 1.75 & 2.53 & 2.27 & 2.27 \\
\hline Lancashire & 2.08 & 2.04 & 1.95 & 2.91 & 2.10 \\
\hline Merseyside & 0.85 & 1.17 & 0.94 & 0.65 & 0.97 \\
\hline East Riding and North Lincolnshire & 6.05 & 7.14 & 6.06 & 4.53 & 6.17 \\
\hline North Yorkshire & 6.35 & 5.83 & 6.93 & 5.83 & 6.47 \\
\hline South Yorkshire & 4.42 & 5.39 & 4.04 & 5.5 & 4.62 \\
\hline West Yorkshire & 8.35 & 8.75 & 8.59 & 7.77 & 8.53 \\
\hline Derbyshire and Nottinghamshire & 7.91 & 7.43 & 7.58 & 10.03 & 7.85 \\
\hline Leicestershire, Rutland and Northampton & 6.16 & 4.52 & 6.35 & 7.44 & 5.96 \\
\hline Lincolnshire & 3.08 & 3.21 & 2.81 & 2.91 & 2.94 \\
\hline Hereford, Worcestershire and Warwickshire & 2.23 & 1.9 & 1.73 & 3.88 & 2.06 \\
\hline Shropshire and Staffordshire & 2.93 & 3.5 & 2.74 & 1.94 & 2.86 \\
\hline West Midlands & 2.93 & 4.23 & 2.67 & 1.62 & 2.98 \\
\hline East Anglia & 4.83 & 3.79 & 5.41 & 4.53 & 4.83 \\
\hline Bedfordshire and Hertfordshire & 2.15 & 2.48 & 2.09 & 2.91 & 2.31 \\
\hline Essex & 2.08 & 2.48 & 2.02 & 2.27 & 2.18 \\
\hline Inner London & 2.82 & 2.77 & 2.81 & 2.91 & 2.81 \\
\hline Outer London & 2.82 & 2.48 & 2.89 & 2.91 & 2.77 \\
\hline Berkshire, Bucks. and Oxfordshire & 2.78 & 2.62 & 2.96 & 3.24 & 2.90 \\
\hline Surrey, East and West Sussex & 4.12 & 3.5 & 4.55 & 3.88 & 4.16 \\
\hline Hampshire and Isle Of Wight & 2.97 & 2.92 & 2.67 & 2.59 & 2.73 \\
\hline Kent & 2.6 & 2.77 & 2.67 & 1.29 & 2.52 \\
\hline Gloucestershire, Wiltshire and N. Somerset & 3.19 & 2.48 & 3.32 & 3.24 & 3.07 \\
\hline Dorset and Somerset & 2.49 & 2.33 & 2.67 & 2.59 & 2.56 \\
\hline Cornwall and Isles Of Scilly & 1.71 & 1.6 & 1.73 & 1.29 & 1.64 \\
\hline Devon & 2.38 & 2.48 & 2.09 & 2.27 & 2.23 \\
\hline Observations & 2381 & 686 & 1386 & 309 & 2381 \\
\hline
\end{tabular}

Source: RDA NBS 
Table A1.3. Turnover and gender diversity: quadratic model.

\begin{tabular}{|c|c|c|c|c|}
\hline \multirow{2}{*}{ Depvar = banded turnover } & \multicolumn{4}{|c|}{ (1) } \\
\hline & OLS & C1 & $\mathrm{C2}$ & C3 \\
\hline \% Female TMT folded & $\begin{array}{c}2.307 * * * \\
(0.230)\end{array}$ & $\begin{array}{c}0.011 \\
(0.329)\end{array}$ & $\begin{array}{c}1.683^{* * *} \\
(0.162)\end{array}$ & $\begin{array}{c}1.477^{* * *} \\
(0.006)\end{array}$ \\
\hline$(\% \text { Female TMT folded })^{2}$ & $\begin{array}{c}-13.192^{* * *} \\
(1.334)\end{array}$ & $\begin{array}{l}-2.718 \\
(1.960)\end{array}$ & $\begin{array}{c}-8.346^{* * *} \\
(1.053)\end{array}$ & $\begin{array}{c}-6.914 * * * \\
(0.043)\end{array}$ \\
\hline Gender-diverse TMT dummy & & & & \\
\hline $\begin{array}{l}\text { Observations } \\
\text { Log-Likelihood } \\
\mathrm{R}^{2} \\
\end{array}$ & $\begin{array}{c}2381 \\
-3950.679 \\
0.374 \\
\end{array}$ & & $\begin{array}{c}2381 \\
-3249.294\end{array}$ & \\
\hline
\end{tabular}

Source: RDA NBS.

Note. Controls as in Table 4, plus folded \% minority ethnic TMT. All models use SIC1 and NUTS2 dummies. HAC standard errors clustered on SIC1. Female TMT linear and quadratic terms are centred on the mean. ${ }^{*} \mathrm{p}<0.1, * * \mathrm{p}<0.05, * * * \mathrm{p}<0.01$ 
Table A1.4 Two-way clustering check, OLS model.

\begin{tabular}{|c|c|c|c|c|}
\hline & (1) & (2) & (3) & (4) \\
\hline & OLS & CGMREG & OLS & CGMREG \\
\hline $\begin{array}{l}\text { \% Minority ethnic TMT } \\
\text { folded }\end{array}$ & $\begin{array}{l}1.070 * * \\
(0.336)\end{array}$ & $\begin{array}{c}1.070 * * * \\
(0.253)\end{array}$ & $\begin{array}{c}1.270 \\
(1.375)\end{array}$ & $\begin{array}{c}1.270 \\
(1.391)\end{array}$ \\
\hline \% Female TMT & $\begin{array}{c}0.054 \\
(0.070)\end{array}$ & $\begin{array}{c}0.054 \\
(0.106)\end{array}$ & $\begin{array}{c}-3.200 * * * \\
(0.343)\end{array}$ & $\begin{array}{l}-3.200 * * * \\
(0.475)\end{array}$ \\
\hline$\%$ Female TMT folded & & & $\begin{array}{c}-0.152 \\
(0.611)\end{array}$ & $\begin{array}{c}-0.152 \\
(0.631)\end{array}$ \\
\hline Gender-diverse TMT dummy & & & $\begin{array}{c}1.570 * * * \\
(0.167)\end{array}$ & $\begin{array}{c}1.570 * * * \\
(0.234)\end{array}$ \\
\hline $\begin{array}{l}\text { Observations } \\
\mathrm{R}^{2}\end{array}$ & $\begin{array}{l}2381 \\
0.361\end{array}$ & $\begin{array}{r}2381 \\
0.361\end{array}$ & $\begin{array}{l}2381 \\
0.374\end{array}$ & $\begin{array}{l}2381 \\
0.374\end{array}$ \\
\hline
\end{tabular}

Source: RDA NBS.

Note. Controls as in Table 4. All models use SIC1 and NUTS2 dummies. HAC standard errors clustered on SIC1 (columns 1 and 3) and on SIC1*NUTS2 (columns 2 and 4). ${ }^{*} \mathrm{p}<0.1,{ }^{* *} \mathrm{p}<0.05,{ }^{* * *} \mathrm{p}<0.01$ 
Table A1.5 Ethnic diversity: linking firms, second-tier metros and urban demographics.

\begin{tabular}{|c|c|c|c|c|c|c|c|c|}
\hline \multirow{2}{*}{ Dependent variable $=$ turnover } & \multicolumn{4}{|c|}{ (1) } & \multicolumn{4}{|c|}{ (2) } \\
\hline & OLS & C1 & C2 & C3 & OLS & C1 & $\mathrm{C2}$ & C3 \\
\hline \% Minority ethnic TMT folded & $\begin{array}{l}1.073 * * \\
(0.333)\end{array}$ & $\begin{array}{l}-0.277 \\
(1.732)\end{array}$ & $\begin{array}{c}1.053 \\
(0.985)\end{array}$ & $\begin{array}{c}-0.242 * * \\
(0.113)\end{array}$ & $\begin{array}{l}1.161^{* *} \\
(0.421)\end{array}$ & $\begin{array}{l}-0.730 \\
(0.948)\end{array}$ & $\begin{array}{l}1.445^{* *} \\
(0.708)\end{array}$ & $\begin{array}{l}-0.294 \\
(0.526)\end{array}$ \\
\hline $\begin{array}{l}\% \text { Minority ethnic TMT * } \\
\text { second tier city-region }\end{array}$ & & & & & $\begin{array}{l}-0.417 \\
(1.416)\end{array}$ & $\begin{array}{l}0.983^{*} \\
(0.505)\end{array}$ & $\begin{array}{l}-1.015 \\
(0.875)\end{array}$ & $\begin{array}{c}1.681 \\
(2.300)\end{array}$ \\
\hline Second-tier city region & $\begin{array}{l}0.349 * * \\
(0.151)\end{array}$ & $\begin{array}{c}0.371^{* *} \\
(0.181)\end{array}$ & $\begin{array}{c}0.389 * * * \\
(0.124)\end{array}$ & $\begin{array}{c}-0.088^{* * *} \\
(0.033)\end{array}$ & $\begin{array}{l}0.350 * * \\
(0.152)\end{array}$ & $\begin{array}{l}0.464 * \\
(0.237)\end{array}$ & $\begin{array}{c}0.301 \\
(0.353)\end{array}$ & $\begin{array}{c}-0.160 * * * \\
(0.045)\end{array}$ \\
\hline \multirow[t]{3}{*}{$\begin{array}{l}\text { Observations } \\
\text { Log-Likelihood }\end{array}$} & $\begin{array}{c}2381 \\
-3974.367\end{array}$ & & $\begin{array}{c}2381 \\
-3340.560\end{array}$ & & $\begin{array}{c}2381 \\
-3974.299\end{array}$ & & $\begin{array}{c}2381 \\
-3319.604\end{array}$ & \\
\hline & \multicolumn{4}{|c|}{ (3) } & \multicolumn{4}{|c|}{ (4) } \\
\hline & OLS & C1 & $\mathrm{C} 2$ & C3 & OLS & C1 & $\mathrm{C} 2$ & C3 \\
\hline \% Minority ethnic TMT folded & $\begin{array}{l}1.073^{* *} \\
(0.333)\end{array}$ & $\begin{array}{l}-0.277 \\
(1.732)\end{array}$ & $\begin{array}{c}1.053 \\
(0.985)\end{array}$ & $\begin{array}{c}-0.242^{* *} \\
(0.113)\end{array}$ & $\begin{array}{l}1.087^{* *} \\
(0.370)\end{array}$ & $\begin{array}{c}1.566^{* * *} \\
(0.512)\end{array}$ & $\begin{array}{l}-0.479 \\
(0.470)\end{array}$ & $\begin{array}{c}-0.589 * * * \\
(0.003)\end{array}$ \\
\hline $\begin{array}{l}\text { TMT * second-tier CR } \\
* \text { minority pop }\end{array}$ & & & & & $\begin{array}{l}-0.006 \\
(0.095)\end{array}$ & $\begin{array}{l}-0.037 \\
(0.042)\end{array}$ & $\begin{array}{c}0.127 \\
(0.125)\end{array}$ & $\begin{array}{c}0.039 * * * \\
(0.000)\end{array}$ \\
\hline Second-tier city region & $\begin{array}{c}0.349 * * \\
(0.151)\end{array}$ & $\begin{array}{c}0.371^{* *} \\
(0.181)\end{array}$ & $\begin{array}{c}0.389 * * * \\
(0.124)\end{array}$ & $\begin{array}{c}-0.088^{* * *} \\
(0.033)\end{array}$ & $\begin{array}{l}0.349^{*} \\
(0.152)\end{array}$ & $\begin{array}{c}0.248 \\
(0.243)\end{array}$ & $\begin{array}{l}0.308^{*} \\
(0.164)\end{array}$ & $\begin{array}{c}-0.129 * * * \\
(0.001)\end{array}$ \\
\hline $\begin{array}{l}\text { Lagged minority ethnic } \\
\text { working age population }\end{array}$ & $\begin{array}{c}0.001 \\
(0.003)\end{array}$ & $\begin{array}{l}0.006^{*} \\
(0.004)\end{array}$ & $\begin{array}{c}0.002 \\
(0.007)\end{array}$ & $\begin{array}{c}-0.005^{* *} \\
(0.002)\end{array}$ & $\begin{array}{c}0.001 \\
(0.003)\end{array}$ & $\begin{array}{l}-0.005 \\
(0.010)\end{array}$ & $\begin{array}{c}0.001 \\
(0.003)\end{array}$ & $\begin{array}{c}-0.009^{* * *} \\
(0.000)\end{array}$ \\
\hline $\begin{array}{l}\text { Observations } \\
\text { Log-Likelihood }\end{array}$ & $\begin{array}{c}2381 \\
-3974.367\end{array}$ & & $\begin{array}{c}2381 \\
-3340.560\end{array}$ & & $\begin{array}{c}2381 \\
-3974.365\end{array}$ & & $\begin{array}{c}2381 \\
-3218.532\end{array}$ & \\
\hline
\end{tabular}

Source: RDA NBS.

Note. Controls as in Table 4. All models use SIC1 and NUTS2 dummies. HAC standard errors clustered on SIC1. ${ }^{*} \mathrm{p}<0.1, * * \mathrm{p}<0.05, * * *$ $\mathrm{p}<0.01$. 
Table A1.6 Homogeneity analysis.

\begin{tabular}{|c|c|c|c|c|}
\hline \multirow{2}{*}{ Dependent variable $=$ turnover } & \multicolumn{4}{|c|}{ (1) } \\
\hline & OLS & C1 & $\mathrm{C} 2$ & C3 \\
\hline All minority-ethnic TMT & $\begin{array}{c}-0.775^{* * *} \\
(0.156)\end{array}$ & $\begin{array}{c}-1.278 * * * \\
(0.347)\end{array}$ & $\begin{array}{c}0.359 * * * \\
(0.129)\end{array}$ & $\begin{array}{c}-0.098 * * * \\
(0.001)\end{array}$ \\
\hline All majority-ethnic TMT & $\begin{array}{c}-0.456 * * * \\
(0.133)\end{array}$ & $\begin{array}{c}-0.595 * * * \\
(0.214)\end{array}$ & $\begin{array}{l}0.288^{*} \\
(0.170)\end{array}$ & $\begin{array}{c}-0.098 * * * \\
(0.001)\end{array}$ \\
\hline $\begin{array}{l}\text { Observations } \\
\text { Log-Likelihood } \\
\mathrm{R}^{2} \\
\end{array}$ & $\begin{array}{c}2381 \\
-3973.794 \\
0.362 \\
\end{array}$ & & $\begin{array}{c}2381 \\
-3034.604\end{array}$ & \\
\hline \multirow{2}{*}{ Dependent variable $=$ turnover } & \multicolumn{4}{|c|}{ (2) } \\
\hline & OLS & C1 & $\mathrm{C} 2$ & C3 \\
\hline All-female TMT & $\begin{array}{c}-0.667 * * * \\
(0.044)\end{array}$ & $\begin{array}{c}-0.747 * * * \\
(0.115)\end{array}$ & $\begin{array}{c}-0.492^{* * *} \\
(0.069)\end{array}$ & $\begin{array}{c}-0.143^{* * *} \\
(0.001)\end{array}$ \\
\hline All-male TMT & $\begin{array}{l}-0.036 \\
(0.044)\end{array}$ & $\begin{array}{c}0.450^{* * *} \\
(0.144)\end{array}$ & $\begin{array}{l}-0.106 * \\
(0.060)\end{array}$ & $\begin{array}{c}-0.249 * * * \\
(0.001)\end{array}$ \\
\hline $\begin{array}{l}\text { Observations } \\
\text { Log-Likelihood } \\
\mathrm{R}^{2}\end{array}$ & $\begin{array}{c}2381 \\
-3953.922 \\
0.373\end{array}$ & & $\begin{array}{c}2381 \\
-3227.564\end{array}$ & \\
\hline
\end{tabular}

Source: RDA NBS.

Note. Controls as in Table 4. All models use SIC1 and NUTS2 dummies. HAC standard errors clustered on SIC1.

${ }^{*} \mathrm{p}<0.1, * * \mathrm{p}<0.05, * * * \mathrm{p}<0.01$. 


\section{Appendix 2 / Finite Mixture Modelling diagnostics}

I estimate a number of Finite Mixture (FMM) models, starting with the simplest two-component version. Convergence is possible up to five components, after which it becomes too fragile to be feasible in the analysis. I choose between models based on overall model fit statistics, component size, component precision and underlying fit to the dependent variable.

Table A2.1 compares overall model fit for the four models estimated. As expected, IC scores mechanically improve with each new component $C$, but for AIC, adjusted BIC and loglikelihood the magnitude of gain falls after four components. Entropy is a measure of the distinctiveness of each component, varying from 0 (everybody has an equal posterior probability of membership in all classes) to 1 (each individual has posterior probability 1 in given class) (Ramaswamy et al., 1993). Intuitively, entropy needs to be over 0.5 for interpretation to be feasible, suggesting at least three components are needed. Iterations required for convergence increase substantially from three to four components, and by an order of magnitude from four to five components.

Table A2.1 about here

Table A2.2 sets out estimated posterior probabilities, from the two-component model (top panel) to the five-component model (bottom). Standard deviations indicate the precision with which the estimator is able to assign observations to classes. Increasing $C$ beyond three leads to some loss of precision in the two largest classes, but subsequent components are increasingly well-fitted. 


\section{Table A2.2 about here}

Table A2.3 sets out the distribution of observations based on most likely class membership. For four and five-component models, some classes become 'small' in the sense that they have under 100 observations. Given the sample size, this could make inference dubious.

\section{Table A2.3 about here}

Table A2.4 gives the average posterior probabilities: these specify the probability that firm $i$ belongs to class $C$ given that we observe Yi, that firm's turnover. As with model fit, this also functions as an indicator of overall 'performance': scores need to be as close to one as possible for the given probability*component cell. Assignment into classes becomes cleaner as $C$ increases. At the margin, is not clear that a five-component model provides overall gains above a four component model, with some classes becoming less precisely ascribed.

\section{Table A2.4 about here}

Taken together, these considerations suggest a three-component model is optimal, although a four-component model is also technically feasible. Figure A2.1 gives the density of the pooled sample against the four components.

Figure A2.1 about here 
Appendix 2 / Figures and tables

Figure A2.1 Histogram / kernel density function, three-component model.

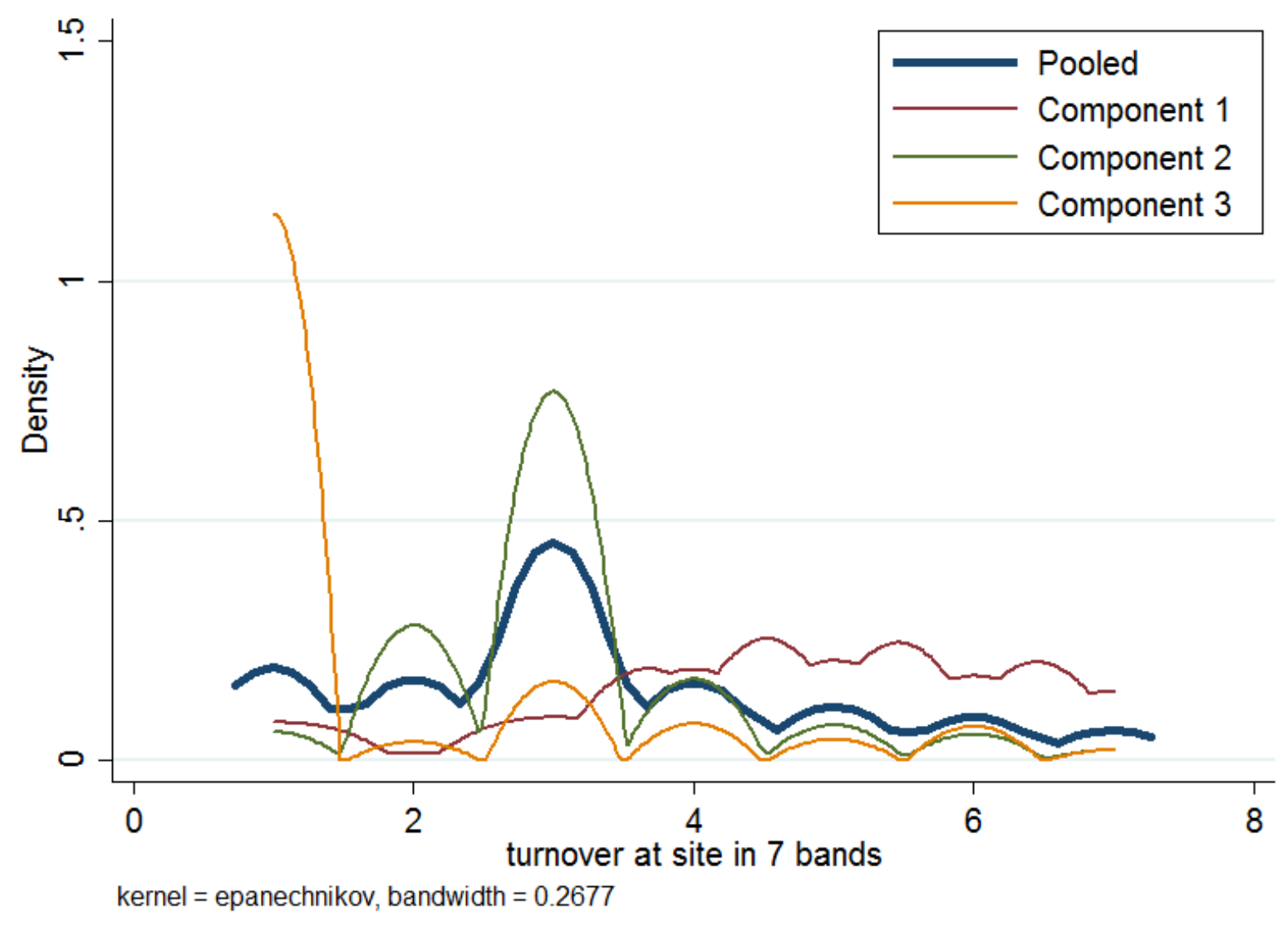

Source: RDA NBS. 
Table A2.1 FMM model fit comparison.

\begin{tabular}{|l|c|c|c|c|}
\hline Components & $\mathbf{2}$ & $\mathbf{3}$ & $\mathbf{4}$ & $\mathbf{5}$ \\
\hline AIC & 7234.696 & 7039.985 & 6612.435 & 6245.781 \\
BIC & 7887.302 & 8021.782 & 7923.423 & 7885.96 \\
Sample size adjusted BIC & 7528.277 & 7481.656 & 7202.195 & 6983.631 \\
\hline \# free parameters & 113 & 170 & 227 & 284 \\
Log likelihood & -3504.348 & -3349.993 & -3079.217 & -2838.891 \\
\hline Entropy & 0.378 & 0.574 & 0.688 & 0.75 \\
\hline Iterations & 19 & 38 & 98 & 1126 \\
\hline
\end{tabular}

Source: RDA NBS.

Table A2.2 Estimated posterior probabilities.

\begin{tabular}{|l|c|c|c|c|c|}
\hline Variable & Obs & Mean & Std. Dev. & Min & Max \\
\hline post2_1 & 2381 & 0.310 & 0.273 & 0.000 & 1.000 \\
post2_2 & 2381 & 0.690 & 0.273 & 0.000 & 1.000 \\
\hline post3_1 & 2381 & 0.437 & 0.328 & 0.000 & 1.000 \\
post3_2 & 2381 & 0.450 & 0.338 & 0.000 & 1.000 \\
post3_3 & 2381 & 0.112 & 0.264 & 0.000 & 0.998 \\
\hline post4_1 & 2381 & 0.460 & 0.342 & 0.000 & 1.000 \\
post4_2 & 2381 & 0.407 & 0.340 & 0.000 & 1.000 \\
post4_3 & 2381 & 0.099 & 0.258 & 0.000 & 0.999 \\
post4_4 & 2381 & 0.034 & 0.179 & 0.000 & 1.000 \\
\hline post5_1 & 2381 & 0.482 & 0.349 & 0.000 & 1.000 \\
post5_2 & 2381 & 0.377 & 0.336 & 0.000 & 1.000 \\
post5_3 & 2381 & 0.073 & 0.236 & 0.000 & 1.000 \\
post5_4 & 2381 & 0.032 & 0.175 & 0.000 & 1.000 \\
post5_5 & 2381 & 0.036 & 0.179 & 0.000 & 1.000 \\
\hline
\end{tabular}

Source: RDA NBS. 
Table A2.3 Classification of subjects based on most likely latent class membership.

\begin{tabular}{|c|c|c|}
\hline Component & Frequency & Percent \\
\hline 1 & 421 & 17.68 \\
2 & 1960 & 82.32 \\
\hline 1 & 742 & 31.16 \\
2 & 1324 & 55.61 \\
3 & 315 & 13.23 \\
\hline 1 & 832 & 34.94 \\
2 & 1183 & 49.69 \\
3 & 283 & 11.89 \\
4 & 83 & 3.49 \\
\hline 1 & 916 & 38.47 \\
2 & 1089 & 45.74 \\
3 & 204 & 8.57 \\
4 & 78 & 3.28 \\
5 & 94 & 3.95 \\
\hline Total & 2381 & \\
\hline
\end{tabular}

Source: RDA NBS.

Table A2.4 Average posterior probabilities.

\begin{tabular}{|c|ccccc|}
\hline \multirow{2}{*}{$\begin{array}{c}\text { Average posterior } \\
\text { probability }\end{array}$} & \multicolumn{5}{|c|}{ Most likely latent class } \\
\cline { 2 - 6 } & LC1 & LC2 & LC3 & LC4 & LC5 \\
\hline post2_1 & 0.835 & 0.165 &. &. &. \\
post2_2 & 0.197 & 0.803 &. &. &. \\
\hline post3_1 & 0.887 & 0.103 & 0.01 &. &. \\
post3_2 & 0.253 & 0.729 & 0.018 &. &. \\
post3_3 & 0.153 & 0.096 & 0.751 &. &. \\
\hline post4_1 & 0.887 & 0.106 & 0.007 & 0 &. \\
post4_2 & 0.266 & 0.723 & 0.01 & 0 &. \\
post4_3 & 0.142 & 0.086 & 0.771 & 0 &. \\
post4_4 & 0.01 & 0.016 & 0.001 & 0.973 &. \\
\hline post5_1 & 0.884 & 0.114 & 0.002 & 0 & 0 \\
post5_2 & 0.282 & 0.715 & 0.002 & 0 & 0 \\
post5_3 & 0.115 & 0.057 & 0.828 & 0 & 0 \\
post5_4 & 0.007 & 0.009 & 0 & 0.984 & 0 \\
post5_5 & 0.061 & 0.023 & 0 & 0 & 0.916 \\
\hline
\end{tabular}

Source: RDA NBS. 